\title{
Strategic Nordic Products - Heat pumps
}

Nordsyn

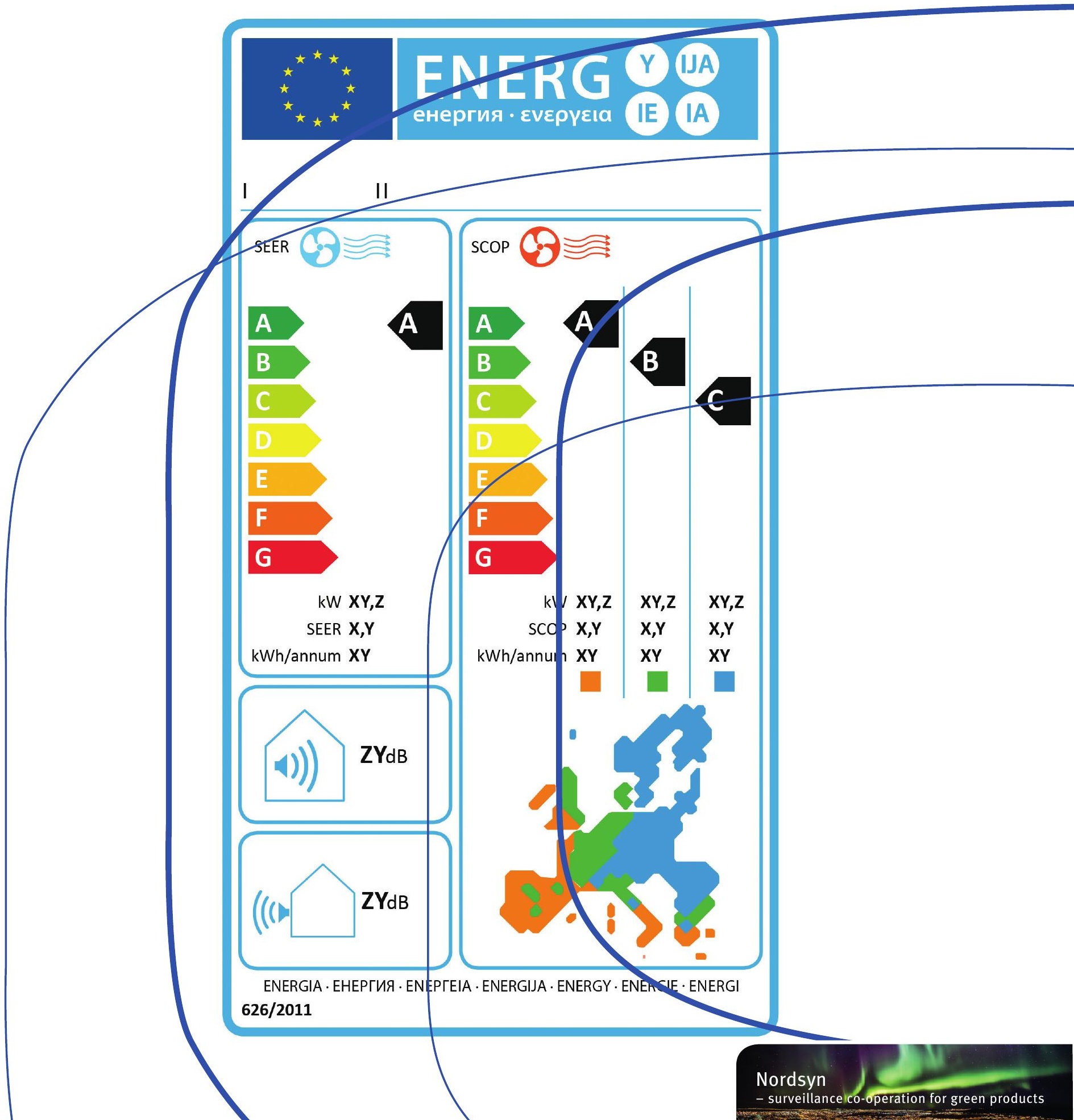



2 norden 



\section{Strategic Nordic Products - Heat pumps}

Nordsyn

Viegand Maagøe A/S 
Strategic Nordic Products - Heat pumps

Nordsyn

Viegand Maagøe A/S

ISBN 978-92-893-4301-5 (PRINT)

ISBN 978-92-893-4303-9 (PDF)

ISBN 978-92-893-4302-2 (EPUB)

http://dx.doi.org/10.6027/TN2015-564

TemaNord 2015:564

ISSN 0908-6692

(c) Nordic Council of Ministers 2015

Layout: Hanne Lebech

Cover photo: from Official Journal of the European Union

Print: Rosendahls-Schultz Grafisk

Printed in Denmark

This publication has been published with financial support by the Nordic Council of Ministers. However, the contents of this publication do not necessarily reflect the views, policies or recommendations of the Nordic Council of Ministers.

\section{www.norden.org/nordpub}

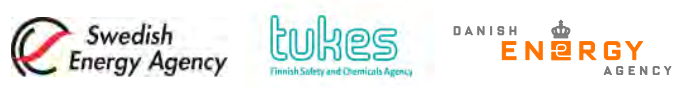

\section{Nomeglan
Water fesureses and
Energy birectorate}

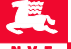

Energy Directorate

\section{Nordic co-operation}

Nordic co-operation is one of the world's most extensive forms of regional collaboration, involving Denmark, Finland, Iceland, Norway, Sweden, and the Faroe Islands, Greenland, and Åland.

Nordic co-operation has firm traditions in politics, the economy, and culture. It plays an important role in European and international collaboration, and aims at creating a strong Nordic community in a strong Europe.

Nordic co-operation seeks to safeguard Nordic and regional interests and principles in the global community. Common Nordic values help the region solidify its position as one of the world's most innovative and competitive.

\section{Nordic Council of Ministers}

Ved Stranden 18

DK-1061 Copenhagen K

Phone (+45) 33960200

www.norden.org 


\section{Contents}

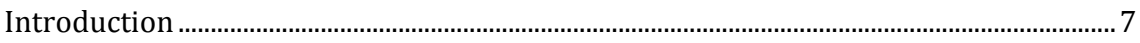

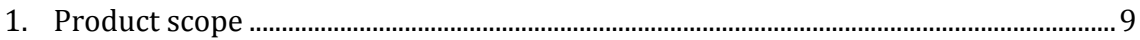

2. Overview of European and Nordic legislations and voluntary schemes and

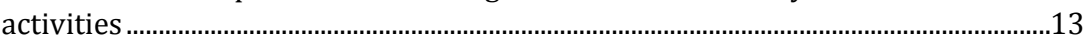

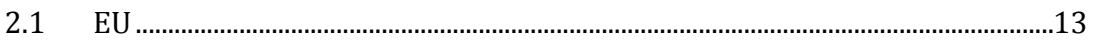

2.2 Denmark

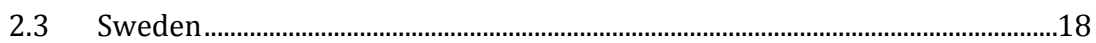

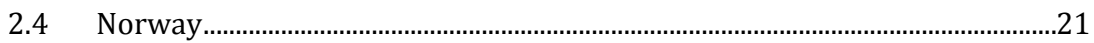

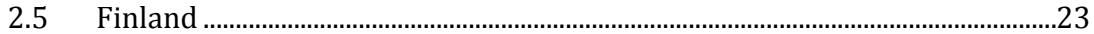

2.6 Iceland ..................................................................................................................23

3. Status and development of heat pumps in Nordic countries.....................................25

4. Market surveillance activities in Nordic countries ......................................................27

5. Climate zones and energy labels......................................................................................31

6. The Danish Energy Agency's heat pump list - "Varmepumpelisten" ..........................39

7. Sound power level ...........................................................................................................43

8. Smart tariffs (Off-Peak tariffs for load shifting) .............................................................4

9. Certified Installers ...........................................................................................................51

10. Recommendations for cooperation and actions .....................................................59

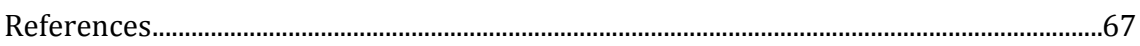

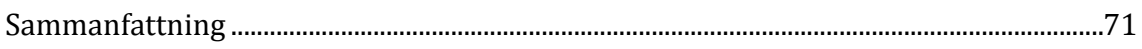

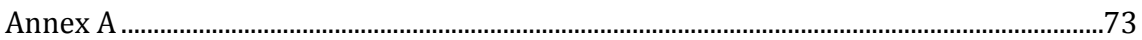

Definitions in EU ecodesign and energy labelling regulations for heat pumps. 



\section{Introduction}

Within the Nordsyn cooperation the Nordic countries - Denmark, Sweden, Norway, Finland and Iceland have launched a project called Strategic Nordic Products. The overall project aims to study products that are strategically important in the Nordic countries from the perspective of green growth and energy efficiency and regarding market surveillance of ecodesign and energy labelling. In an earlier project the Nordic countries chose heat pumps to be the Strategic Nordic Products to study closer in the present project. Heat pumps are strategic Nordic products as their optimization is affected by climate and there is a strong industry and history in the Nordic countries. Hence it is important to investigate how the Nordic authorities should handle these products in terms of policymaking and market surveillance.

The objectives of this study is to create an overview of legislations, national schemes and actions taken to promote energy efficient heat pumps, while discussing a number of issues arising from the ecodesign and energy labelling regulations of heat pumps and market surveillance activities. The study concludes the points of discussions and makes recommendations from the consultants of further actions that could be carried out by Nordic authorities.

This report is part of the Nordic Prime Ministers green growth initiative under the Nordic Council of Ministers. See more on www.norden.org/ greengrowth 



\section{Product scope}

The product scope of this project corresponds with the heat pumps covered in ecodesign and energy labelling regulations 2013/813/EU, 2013/811/EU, 2013/812/EU, 2013/814/EU 2012/206/EU and 2011/626/EU. The full definitions can be found in the Annex. In general, the covered products include the following three main types of heat pumps and combinations of products:

Air to air heat pumps (covered by Regulation 2012/206/EU and 2011/626/EU) are heat pump space heaters, also commonly known as air conditioners. Air to air heat pumps convert heat from typically outdoor air and give out heat to indoor air and are the most common types in the Nordic countries. Some air to air heat pumps can provide both cooling and heating, these can also be found in Northern Europe, but cooling only air to air heat pumps are more commonly found in central and Southern Europe.

Figure 1. Example of how air to air heat pumps work (sparenergi.dk)

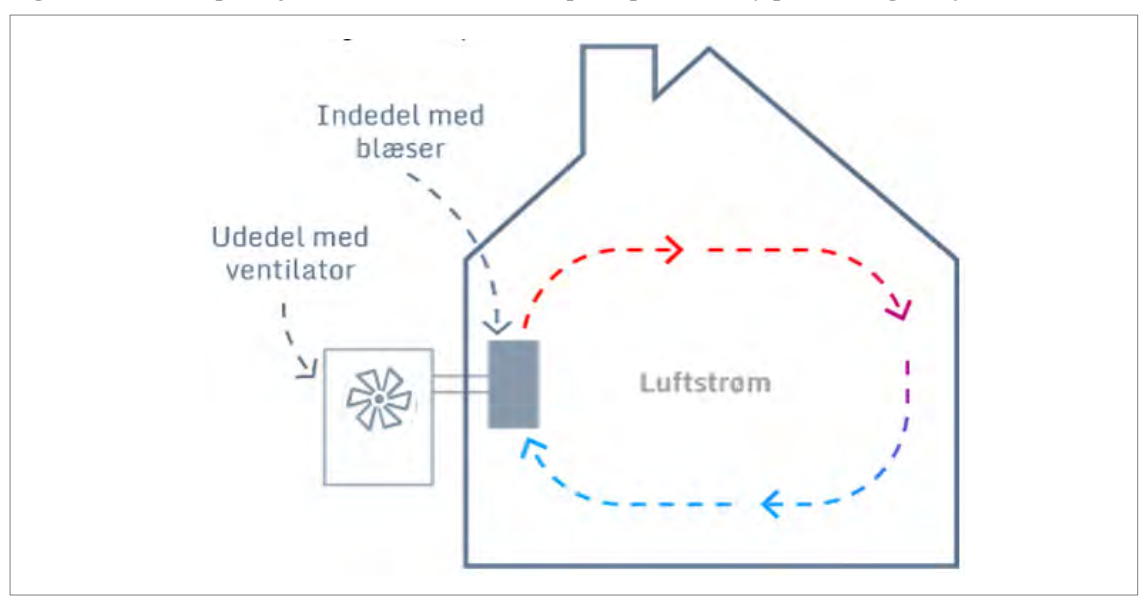

Air to water heat pumps (covered by Regulation 2013/813/EU, 2013/811/EU, 2013/812/EU, and 2013/814/EU) can be heat pump space heaters or combination heaters. Air to water heat pump space heaters convert heat from typically outdoor air and transfer the heat to water, which circulates to radiators. Combination heaters transfer the heat to water, which both circulates to radiators and supplies domestic 
hot water demand. If the heat pump only transfer heat to water that supplies domestic hot water demand, these are heat pump water heaters, which are seldom found in some countries like Denmark, but more common in Norway.

Figure 2. Example of how air to water heat pump combination heaters work (sparenergi.dk)

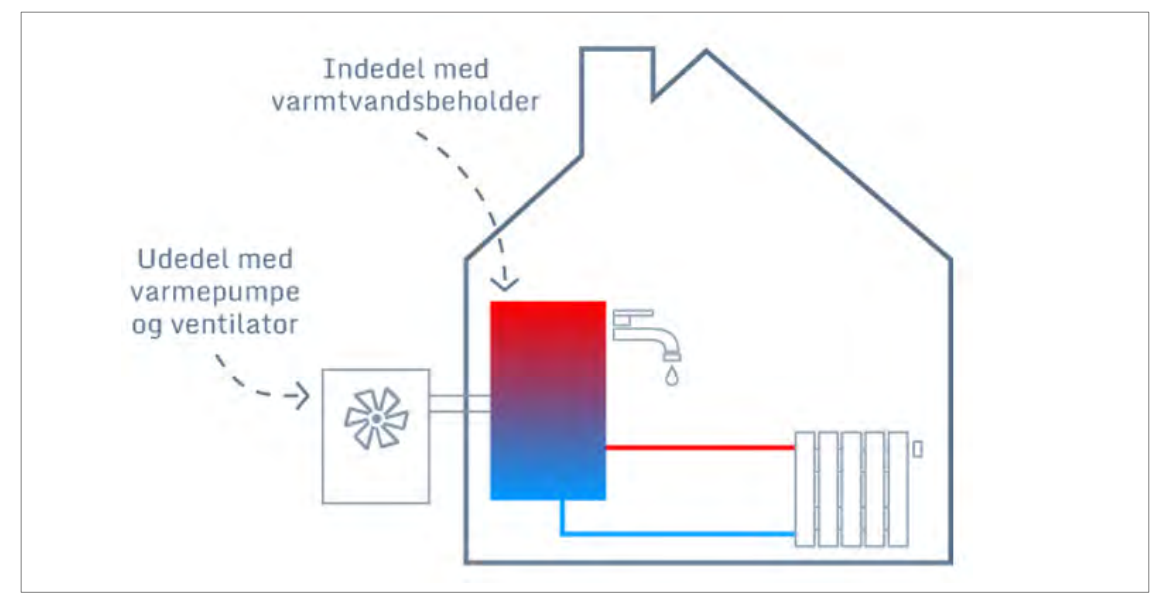

Liquid to water heat pumps (covered by Regulation 2013/813/EU, 2013/811/EU, 2013/812/EU, and 2013/814/EU) can be heat pump space heaters or combination heaters that use working fluid to transfer heat from different heat sources to water which circulates to radiators or supplies domestic hot water. If a heat pump only transfers heat to water that supplies domestic hot water demand, these are heat pump water heaters. There are a few different types of liquid to water heat pumps, such as Water Source Heat Pumps (WSHP), ${ }^{1}$ Lake Source Heat Pumps (LSHP), and Ground Source Heat Pumps (GSHP).

${ }^{1}$ These heat pumps extract heat energy from water in lakes, springs, wells, and ponds etc. water sources. 
Figure 3. Example of how liquid to water heat pump (GSHP) combination heaters work (sparenergi.dk)

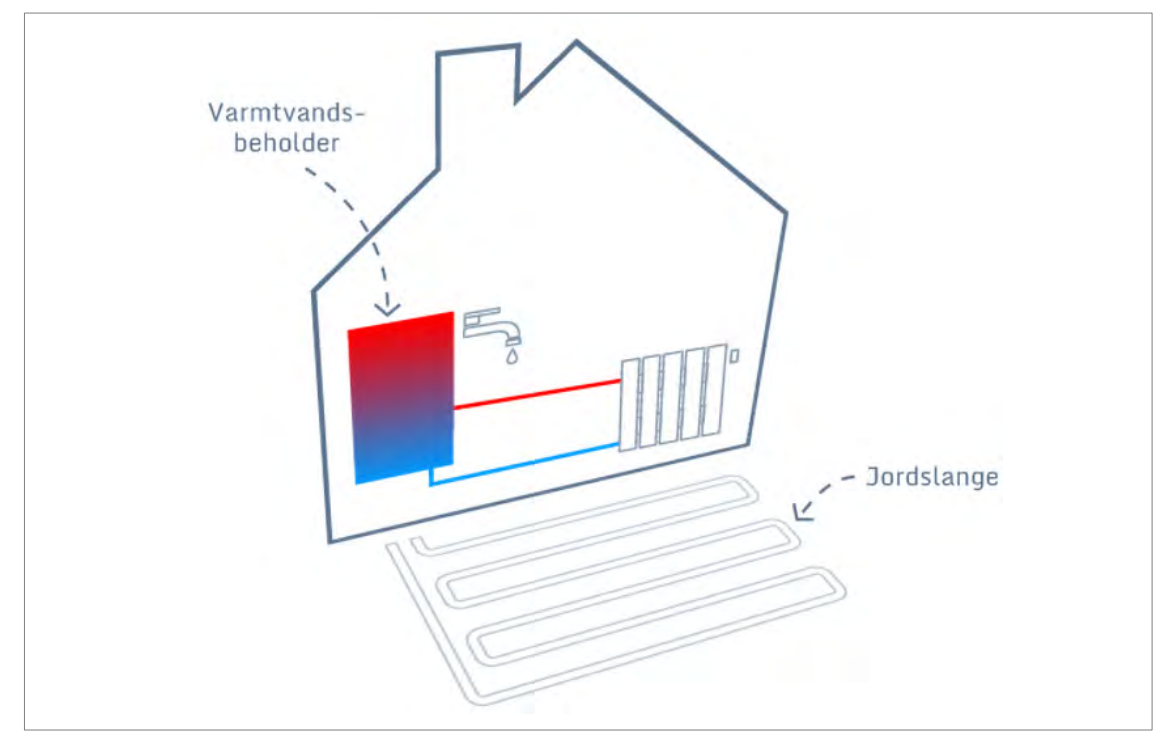

Package products (covered by Regulation 2013/811/EU and 2013/812/EU) are combination of space or water heating products sold as a package. Any combination of heat pump space heaters or water heaters, temperature controls, solar devices, and any supplementary heating device can be sold together as a package product. The package products are covered by EU regulation and have to display energy labels designated for package products.

Figure 4. Example of how a package of solar device, hot water storage tank and an air to water heat pump work (images from sparenergi.dk with author's edition) 



\section{0}

\section{Overview of European and Nordic legislations and voluntary schemes and activities}

In order to forge a strong collaboration between the energy authorities and Market Surveillance Authorities (MSA) in the Nordic countries, it is important to have an overall picture of what has been done and is going on in the EU and Nordic countries concerning heat pumps. This section gives an overview of existing EU legislations, and national legislations, incentives and voluntary schemes on heat pumps.

\section{$2.1 \mathrm{EU}$}

The European Commission has adopted regulations that cover various types of heat pumps on the EU market. Existing EU regulations on air conditioners (air to air heat pumps) have become effective on the 1st January 2013 and will be due for revision in March 2017. Regulations regarding heat pumps (including package products) become effective on the 26th September 2015. The relevant ecodesign and energy labelling regulations are listed as follows:

- Ecodesign regulation on air conditioner (EU) No 206/2012.

- Energy labelling regulation on air conditioners (EU) No 626/2011.

- Ecodesign regulation on boilers and heat pumps (EU) No 813/2013.

- Energy Labelling regulation on boilers, heat pumps and packages (EU) No 811/2013.

- Ecodesign regulation on water heaters and heat pump water heaters (EU) No 814/2013.

- Energy Labelling regulation on water heaters, heat pump water heats and hot water storage tanks and packages (EU) No 812/2013. 
The purpose of the ecodesign regulations is to remove the less efficient products from the market. Ecodesign regulations include minimum efficiency requirement for heat pumps, requirements for maximum allowed sound power level etc. and requirements for product information in manuals for installers and users and on websites of the manufacturer.

Energy labelling regulation aims to promote energy efficient heat by making the products energy efficiency class visible to the consumers in a standardised manner.

Further details of the ecodesign and energy labelling requirements are described in Section 5.

\subsection{Denmark}

The Danish Government has a target to phase out oil and gas boilers by respectively 2030 and 2035. Heat pumps are expected to play a key role in achieving the target.

This section summarises the national legislations for heat pumps and mentions important initiatives taken in Denmark to promote the energy efficiency and quality of heat pumps.

\section{Requirements for heat pumps in the Danish Building Regulations (BR10) $^{2}$}

BR10 includes requirements on air to air, air to water, and liquid to water heat pumps. It is required that air to air heat pumps must have an efficiency in heating mode no less than 3.6 corresponding to EU energy labelling class A of household air conditioners. This is now equivalent to the minimum energy efficiency requirement set by the EU ecodesign regulation regarding air to air heat pumps, therefore revision of BR10 requirements on air to air heat pump should be considered.

Air to water and liquid to water heat pumps must have a nominal power factor of no less than requirements specified by the Danish Energy Agency's (DEA) which is depending on the size and whether the system supplies underfloor heating systems/radiators. The requirements by DEA are more ambitious than the EU ecodesign requirements for air to water and liquid to water heat pumps.

2 Requirements for heat pumps in the Danish Building Regulations (BR10): http://anvisninger.dk/ Publikationer/Sider/Anvisning-om-Bygningsreglement-2010.aspx/8-Installationer/8-6-Solvarmeanlaegsolcelleanlaeg-koeleanlaeg-og-varmepumper/8-6-4-Varmepumper-og-koeleanlaeg 
BR10 also includes requirements for the heat pump system if it uses hazardous liquids or gases and for the designing and commissioning of the systems. With respect to noise BR10 includes requirements for noise power level both for outdoor and indoor conditions. The requirements are based on recommended noise limits from the Danish Environmental Protection Agency. See Figure 5. The limits are not a specific requirement for the outdoor unit of the heat pump, but it is the general environmental requirement for allowed loud power level in proximity to neighbours and outdoor living areas.

Figure 5. Extract of noise requirements from the Danish Environmental Protection Agency

\begin{tabular}{|c|c|c|c|}
\hline \multirow[t]{2}{*}{ Døgnperiode } & \multicolumn{3}{|c|}{ Støjgrænse $L_{r}$ for boligområder } \\
\hline & $\begin{array}{l}\text { Sommerhus- } \\
\text { områder }\end{array}$ & $\begin{array}{c}\text { Tæt lav boligområde } \\
\text { (parcelhuse, række- } \\
\text { huse mv.) }\end{array}$ & $\begin{array}{c}\text { Etageboliger } \\
\text { Blandet bolig og } \\
\text { erhverv } \\
\text { Det åbne land (en- } \\
\text { keltliggende huse) }\end{array}$ \\
\hline $\begin{array}{l}\text { Hverdage kl. } 07-18 \\
\text { Lørdage kl. } 07-14\end{array}$ & $\mathrm{~L}_{\mathrm{r}} \leq 40 \mathrm{~dB}$ & $L_{r} \leq 45 \mathrm{~dB}$ & $L_{r} \leq 50-55 \mathrm{~dB}$ \\
\hline $\begin{array}{l}\text { Hverdage kl. } 18-22 \\
\text { Lørdage kl. } 14-22 \\
\text { Søndage kl. } 07-22\end{array}$ & $L_{r} \leq 35 \mathrm{~dB}$ & $\mathrm{~L}_{\mathrm{r}} \leq 40 \mathrm{~dB}$ & $\mathrm{~L}_{\mathrm{r}} \leq 45 \mathrm{~dB}$ \\
\hline Alle dage kl. $22-07$ & $L_{r} \leq 35 \mathrm{~dB}$ & $L_{r} \leq 35 \mathrm{~dB}$ & $L_{r} \leq 40 \mathrm{~dB}$ \\
\hline
\end{tabular}

For indoor conditions the sound power level should be below or equal to $30 \mathrm{~dB}$. For air to water heat pump the requirement for indoor sound power level is normally not a problem, if the system is installed properly. ${ }^{3}$

\section{Reduction in heat pump electricity cost for large-scale consumers}

Denmark promotes the use of heat pumps by reducing the fixed electricity fees for electric space heater and heat pumps users. For consumers whose energy consumption is typically over $4,000 \mathrm{kWh}$, there is a reduction in cost: the unit price for electricity used for space heating and heat pumps is reduced to DKK 0.0419 per $\mathrm{kWh}$ instead of DKK 0.0847 per $\mathrm{kWh}$ normally (VAT excluded), the fee reduction is true for 2015 at the time of writing the report. ${ }^{4}$

${ }^{3}$ Styr på støjen - en guide til installation af luft til vand varmepumper. Udarbejdet for Energistyrelsen, december 2012. Grontmij.

${ }^{4}$ http://www.skat.dk/SKAT.aspx?oID=2061620\&chk=209219 


\section{Danish heat pump list - "Varmepumpelisten"}

The DEA has launched a list, called "Varmepumpelisten" on the consumer website SparEnergi.dk. This list helps the Danish consumers to find energy efficient heat pumps on the market. See details in Section 6.

\section{Independent advice service}

Danish Energy Agency has established a free and independent advice service for consumers who want to replace old oil and gas fired boilers with heat pumps. ${ }^{5}$ The advice service is taken care of by a partnership consisting of Energitjenesten, Bolius and Technological Institute. The advice service include a telephone-service open every day from 10-16 (Thursday from 10-20) and possibility to have questions answered via e-mail. Also information meetings are held.

\section{Dissemination of information}

The DEA has developed brochures targeted at the installers and contractors, so they can recognise and understand the information and icons on the new energy labels for all types of heat pumps covered by EU regulations.

In addition, information brochures aimed at the consumers are also developed to promote the certified installers. Read more about certified installers in Section 9.

On the consumer's website SparEnergi.dk, there is information concerning many aspects of appropriate installing of heat pumps. The consumers can obtain cost savings, payback periods from an online calculator (Ny Varme), choose the product from the "Varmepumpelisten" mentioned above, find the approved installers from the digital tool "Håndværkerlisten" (Craftsmen's list), as well as read case studies and good advice etc. There are also advice concerning location of GSHP and air to water heat pumps due to noise, however no information about how to choose a heat pump with good sound power level.

\section{Study of policy measures for heat pump market growth 6}

The aim of the study was to require insight into the measures which have been implemented in other markets to facilitate and drive growth in heat pumps, how successful these measures have been, and their rele-

\footnotetext{
${ }^{5} \mathrm{http}: / /$ sparenergi.dk/forbruger/varme/raadgivningstjeneste

${ }^{6}$ Policy measures for heat pump market growth, DELTA Energy \& Environment for Danish Energy Agency, December 2013
} 
vance to the Danish context. The key learnings from the project are the following 7 points:

1. A strong Heat Pump Association with participation from across the heating and energy industries has a vital position in driving the market growth - as seen in Sweden, Germany and Switzerland.

2. Building consumer confidence in heat pump technology is a critical first step - this is particularly evident in Switzerland, where installers soon engaged once end-user requests came.

3. There must be quality and confidence permeating the whole value chain - installers and contractors must trust heat pump technology, and consumers must trust the quality of the product, installation and on-going maintenance.

4. Promotion must come after quality - so the market has stable foundations upon which to grow. Switzerland is the clearest example of how effective this can be.

5. A grass-roots level promotion programme focused on and involving local communities can most effectively build confidence - it's effectiveness in building a "critical mass" in one geographical area is seen, for example, in RWE's core region in NRW Germany, or in the Swiss Promotion Programme's focus on individual cantons.

6. Incentives are not critical - but tilting the playing field towards heat pumps helps to trigger customer interest - Heat pump tariffs in Switzerland and Germany, and the taxation on oil in Sweden are examples of this.

7. Heat contracting is still embryonic, but it represents opportunities, particularly in retrofit. There is not yet a proven template to follow, but models which overcome the upfront cost and reduce the customer's perceived risk of a new technology, could make significant in-roads into the market. 


\subsection{Sweden}

This section presents the national schemes and examples of actions taken to promote the use of heat pumps in Sweden.

\section{Heat pump tests by the Swedish Energy Agency}

The Swedish Energy Agency has been testing heat pumps since 2004. The purpose of these tests is to help consumers to choose a heat pump that best fits their needs with regards to energy efficiency, noise levels, price and quality. The tests are published on the Energy Agency's website and are frequently used in marketing by manufacturers. The webpage presenting test results of heat pumps had about 366,000 visits in 2014 alone. As these tests are highly valued by consumers because of their objectivity, their marketing value to manufacturers is high. In this way the tests work as a sort of competition in energy efficiency, driving developments in heat pump technology especially adapted to the Nordic climate.

Since 2004 around 50 air-to-air heat pumps have been tested, 14 ground source heat pumps, 16 air to water heat pumps and 3 exhaust air heat pumps. Laboratory tests can reveal the performance of heat pumps and create an overview of products on the current market. The results show the seasonal coefficient of performance (SCOP), coefficient of performance (COP) for different temperature levels, noise level, investment costs and energy savings for different sizes of households (in terms of heating energy demand) etc. In these tests the conditions are set by the Swedish Energy Agency. Some of them are paid for by the Agency and some by the manufacturers. In return they can use the test results in their marketing campaigns.

In addition to these tests the Swedish Energy Agency also performs market surveillance tests on heat pumps that have active Ecodesign and/or Energy labelling requirements (currently only air-to-air heat pumps). So far 8 air-to-air heat pumps have been tested for market surveillance purposes. Market surveillance tests have not been published on the website. 


\section{Field measurement tests of ground source heat pumps}

In 2012-2014, the Swedish Energy Agency performed field measurement tests of 20 ground source heat pumps in south-west Sweden. The purpose of the measurements was to investigate how effective the heat pump systems are under actual circumstances outside the laboratories, and over time. The project was the biggest of its kind in Sweden. The efficiency varied considerably between different systems, due both to performance of the heat pumps and installation aspects. A summary of the results can be found in the Agency's heat pump report. ${ }^{7}$

\section{Research program for more effective cooling and heat pump systems, Effsys}

The heat pumps technical development and importance as a heating option in Sweden today is largely due to governmental efforts on energy research. Between 1975 and 2008 the government invested around SEK 200 million at R\&D within the heat pump sector, an investment that paid off in only four to five days in terms of "free" energy delivered (1517 TWh 2008) and a price for electricity of SEK $1 / \mathrm{kWh} .{ }^{8}$ At the same time the industry has invested three to four times more, which indicates an effective involvement of the industry with the state as catalyst.

The Swedish Energy Agency has decided to, together with SKVP (the Swedish cooling and heat pump association) implement a four-year long research programme in which the industry, universities and the Swedish Energy Agency cooperates on research, development and innovation within resource efficient cooling and heat pump systems and cooler and heat storage. The total budget of the programme is SEK 96 million, of which the Swedish Energy Agency contributes with SEK 48 million during the period 1st September 2014 till 1st September 2018. The overall purpose of the programme is to contribute to societies and the world's adaption to a more resource efficient and sustainable energy use and a reduction of environmentally harmful substances in thermal storages and heat pump systems.

\section{P-marking by Technical Research Institute of Sweden (SP)}

Sweden has its own certification scheme P-marking on many products, including air to air, air to water, and liquid to water heat pumps. Heat pumps marked with SP's P-marking must fulfil the requirements in the SP

\footnotetext{
${ }^{7}$ Energimyndigheten, Värmepumparnas roll på uppvärmningsmarknaden, ER 2015:09.

${ }^{8}$ Heta Värmepumpar-Sverige ledande på pumpar, Energimyndigheten 2009, ET2009:23.
} 
Certification Rules CR130. The requirements are established in agreement with manufacturers and Swedish authorities. The requirements concern efficiency, sound level, safety and design, and documentation on quality assurance of production etc. ${ }^{9}$ There is a list of P-marking certified heat pumps on SP's website, however there is currently only a few heat pumps displayed on the list. To be allowed to use P-marking on their products, the manufacturer would need to make an application and submit it along with test reports, technical drawing, specifications, user manual, information to installers, and description of quality assurance of the production etc. to SP, who will then examine the documents.

The tests are financed by the manufacturers themselves, and carried out by an accredited laboratory. The procedure of obtaining a P-marking echoes the one for the Danish heat pump list, however with some variations in requirements.

The sound power level requirement is more or less in line with the EU ecodesign regulations for heat pumps. P-marking certification rules also include cold climate conditions. In order to qualify for P-marking, SCOP for "colder climate", as defined in EN 14825, must be declared. If the supplier has declared values for a colder climate, a number of operating points are tested in order to verify the values. If such values have not been declared, the heat pump is tested for all the operating test points for the colder climate. ${ }^{10}$ However requirement to obtain the Pmarking for SCOP is still based on average climate conditions.

\section{Information dissemination}

99\% of the air to air heat pumps on the Swedish market are imported from outside EU, and they are already labelled when they get here. The Swedish Energy Agency has made efforts to inform the dealers about the new energy label though. For example, the Agency has arranged open information meetings to inform producers and other stakeholders about the ecodesign requirements and the energy label.

For other heat pumps, the Swedish Energy Agency has held several stakeholder meetings during the ecodesign regulation process. The latest one was held in October 2014. The Agency is also working on preliminary

\footnotetext{
${ }^{9} \mathrm{http}: / /$ www.sp.se/SV/INDEX/SERVICES/CERTPROD/CERTPRODPROFIL/BYGG/UPPVARMN/ VARMEPUMPAR/Sidor/default.aspx

${ }^{10}$ http://www.sp.se/sv/units/energy/Documents/ETk/CR\%20130\%20september\%202014_141001_ english.pdf
} 
answers to questions raised by the industry and has commented on the European Commission's guideline to the new heat pump regulations.

The Swedish Energy Agency also has a website on which information on several aspects regarding heat pumps can be found. This includes the technical aspects and advice wheninstalling heat pumps, and information on the ecodesign and energy labelling requirements. The Agency also sends an information e-mail to a large number of recipients around 10 times each year with the latest news on the ecodesign and energy labelling area.

Further information activities regarding ecodesign and energy labelling of heat pumps will be planned continuously, concerning possible factsheets, fairs, channels and target groups.

The Swedish Energy Agency has also published a heat pump report in which most aspects of heat pumps in Sweden are covered, ${ }^{11}$ e.g. statistics, barriers and possibilities, potential and the Swedish Energy Agency's research programme on heat pumps. The report can be found in the web shop on the Agency's website. ${ }^{12}$

\subsection{Norway}

The Norwegian Government has a target to phase out fossil oil fuelled boilers by 2020 . Renewables and heat pumps are expected to play a key role in achieving the target. This section presents the national schemes and actions taken to promote the use of heat pumps in Norway.

\section{Enova subsidies}

Enova is an organisation that supports environmental and energy actions and offers subsidies for energy efficient improvements for consumers. Enova has supported heat pump investment in household since 2003. Although the support for air to air heat pumps came to an end in 2006, the Enova subsidies can still be applied for air to water and liquid to water heat pumps. The consumers can get the heat pump systems installed, and send the receipt or invoice in order to receive the subsidy payment. ${ }^{13}$ Consumers can get subsidies between NOK 10,000-20,000 for air to water heat pumps and between NOK 20,000-30,000 for liquid

\footnotetext{
${ }^{11}$ Energimyndigheten, Värmepumparnas roll på uppvärmningsmarknaden, ER 2015:09.

12 https://energimyndigheten.a-w2m.se/Home.mvc

${ }^{13} \mathrm{http}: / /$ www.varmepumpeinfo.no/content/stotte-til-varmepumper-fra-enova
} 
to water heat pumps. ${ }^{14}$ The criteria for subsidies include that the heat pump must be installed by an F-gas certified installer and the heat pump cannot be installed longer than 12 months ago. If the consumers install an energy meter, they can achieve additional economic support.

Enova also supports commercial companies (heating plants etc.) to invest in renewable heating solutions including heat pump solutions. There are two support programmes companies can apply according to their situation. ${ }^{15}$ Under this scheme installation of energy meter is required for obtaining the subsidy.

\section{NOVAP installer certification}

Consumers are encouraged to choose NOVAP-certified dealers when purchasing heat pump products and systems, as their professional competence is recognised and approved by the Norwegian heat pump association (NOVAP). ${ }^{16}$ The consumers are better ensured against technical mistakes in sizing and installation of the system if they choose NOVAPcertified dealers. Read more about certified installers in Section 9.

\section{Information dissemination}

Enova has comprehensive information air to air, air to water and liquid to water heat pumps on their website, including advantages and disadvantages, placing the heat pumps, typical energy/cost savings and checklists for buying heat pumps.

Enova has developed a consumer guide about air to air heat pumps, ${ }^{17}$ which also includes information of hiring F-gas certified installers, and night time noise requirement by the Norwegian Building Regulation. Enova has published two guidelines on energy metering of heat pumps. The "Veileder for installasjon av energimåling av varmepumper" is a guideline for the installer and the "Råd om energimåling av varmepumper for boligeier" is a guideline for the homeowner. Moreover "Enova Svarer" has received about 50,000 enquiries a year, which also includes question about heat pumps.

The Norwegian Consumer Council ("Forbrugkerrådet") has also compiled useful information about the choosing, installing and operating

\footnotetext{
14 http://www.enova.no/finansiering/privat/slik-stotter-vi-deg/vare-tilbud/904/0/

$15 \mathrm{http}$ //www.enova.no/finansiering/naring/fornybar-varme/program-for-varmesentraler/120/0/

$16 \mathrm{http://www.varmepumpeinfo.no/forhandlere}$

${ }^{17} \mathrm{http}: / / \mathrm{www} 2$. enova.no/publikasjonsoversikt/publicationdetails.aspx?publicationID=659
} 
of heat pumps under one webpage. ${ }^{18}$ "Forbrugkerrådet" has also published articles disseminating the heat pump test results from the Swedish Energy Agency, as many of the heat pumps tested by the SEA are also on sale in Norway. ${ }^{19}$ The dissemination of test results included the noise aspects of the heat pumps, and information about the sound power level expressions. Although there is information about the relation between climate and heat pumps, there is no mentioning of the new energy labels or the European climate zones.

\subsection{Finland}

This section presents the national actions taken to promote the use of heat pumps in Finland.

\section{Information dissemination}

Finland has sent out information to suppliers and dealers on the upcoming requirements and energy labels on heat pumps. The Finland authority usually holds ecodesign forums, sends out newsletters about the updates of ecodesign and energy labelling regulations, and answers questions that arise from manufacturers and dealers. There is no other planned activity on heat pumps for the near future to the authors' knowledge at the time of writing this report.

\subsection{Iceland}

No information has been available.

\footnotetext{
${ }^{18} \mathrm{http} / /$ www.forbrukerradet.no/annet/tester-og-kj\%C3\%B8petips/produkter/den-storevarmepumpeguiden

${ }^{19} \mathrm{http}$ ://www.forbrukerradet.no/annet/tester-og-kj\%C3\%B8petips/produkter/rekordresultater-for-nyvarmepumpe
} 



\section{Status and development of heat pumps in Nordic countries}

A development of energy efficiency and quality in heat pumps can be observed in the Nordic countries over the past years.

The development of air to air heat pumps has been observed via the market surveillance process. Air to air heat pumps are widely sold in the Nordic countries, at the time of writing this report, many of them can achieve seasonal energy efficiency class $A$ and above, and more heat pumps with $\mathrm{A}+++$ label starts to emerge on the market. As seen in Table $1, \mathrm{~A}+++$ is set as a benchmark by ecodesign regulation for air to air heat pumps.

Before 2013, approximately half of the products being controlled have failed in terms of compliance with ecodesign requirements or because of wrongly declared energy classes etc. In 2013-2014, Danish Market Surveillance Authority (MSA) found all of the controlled products to be compliant, and Swedish MSA found only minor non-compliant issues.

Over the years, it has been observed by the Danish heat pump experts that the heat pumps with poorest performances and quality are disappearing from the Danish market gradually. This result could be driven by the "Varmepumpelisten" together with the EU regulations. As "Varmepumpelisten" addresses, among others, the need for an accredited tests and EU regulations emphasise on energy efficiency and test methods.

\begin{tabular}{|c|c|c|c|c|c|}
\hline & & \multicolumn{2}{|c|}{ Ecodesign Min. Requirements } & \multicolumn{2}{|c|}{ Ecodesign Benchmarks } \\
\hline & & Efficiency & $\begin{array}{l}\text { Equivalent } \\
\text { class }\end{array}$ & Efficiency & $\begin{array}{l}\text { Equivalent } \\
\text { class }\end{array}$ \\
\hline Air to air HP & SCOP & 3.42 & A & 5.10 & At++ \\
\hline HP space heaters & Space heating & $100 \%$ & $A+$ & $145 \%$ & A++ \\
\hline $\begin{array}{l}\text { HP combination } \\
\text { heaters }\end{array}$ & Water heating & $\begin{array}{l}\text { Depending on } \\
\text { load profile }\end{array}$ & $\mathrm{E}$ & $\begin{array}{l}\text { Depending } \\
\text { on load }\end{array}$ & A \\
\hline HP water heaters & Water heating & & & profile & \\
\hline
\end{tabular}


Market surveillance activities for other types of heat pumps have not yet been carried out, and therefore the development of efficiency has not been observed. The benchmarks set in ecodesign regulations for the different types of heat pumps are present in Table 1. Following air to air heat pumps' trend, within a few years of regulations' entry into force, an increase in efficiency and quality could be observed as well for the other types of heat pumps. 


\section{Market surveillance activities in Nordic countries}

This section gives a status of market surveillance activities in the Nordic countries up to the time of writing this report. Recommendations to how the MSAs can collaborate better will be discussed in more details in Section 31 in connections with issues related to heat pump regulations.

A report on market surveillance in Nordic countries by T.F. Larsen shows that since 2009 the Nordic countries have tested 139 air to air heat pumps, ${ }^{20}$ out of which 129 are tested by the Danish MSA and 10 by the Swedish MSA. Finland, Iceland and Norway have not tested any new heat pumps.

In Norway, Enova and Norwegian HVAC Association carried out field measurements of 15 household heat pumps in and around Oslo. The field measurements covered air to water and liquid to water heat pumps with different system designs. The results show that some perform poorly with a COP of 1.25 , while some performs very well with a COP of around 4.

Finland has carried out document controls on air to air heat pumps, and informed that the energy labels have so far only been indicating energy efficiency class for average climate conditions.

The 2013 result of market surveillance from the Danish MSA showed that all controlled products (air to air heat pumps/air conditioners) have met the requirements. ${ }^{21}$ The market surveillance consisted of technical documentation control, laboratory tests and unannounced shop visits.

The laboratory test ordered by the Danish MSA did not include the test of sound power levels and cooling performance, but based on the technical documentation control the sound power levels have met the ecodesign requirements. The historical results before 2013 show that more products did not meet the requirements in periods up to the start

20 T.F. Larsen (2014). NORDSYN Market surveillance effects and costs.

${ }^{21} \mathrm{http}: / /$ www.ens.dk/sites/ens.dk/files/forbrug-besparelser/apparater-produkter/tilsyn-

kontrol/kontrolresultater/kontrol_klimaanlaeg.pdf 
of 2013, and it can be concluded that manufacturers are becoming more familiar with the requirements on air to air heat pumps over the years.

\begin{tabular}{|c|c|c|c|c|c|}
\hline Country & Air to air HP & $\begin{array}{l}\text { HP Space } \\
\text { heaters }\end{array}$ & $\begin{array}{l}\text { HP Combinati- } \\
\text { on heaters }\end{array}$ & $\begin{array}{l}\text { HP Water } \\
\text { heaters }\end{array}$ & HP Packages \\
\hline Denmark & $\begin{array}{l}\text { TD control, } \\
\text { testing, shop visit }\end{array}$ & $\begin{array}{l}\text { Plan to take } \\
\text { place in } 2016\end{array}$ & $\begin{array}{l}\text { Plan to take } \\
\text { place in } 2016\end{array}$ & $\begin{array}{l}\text { Plan to take } \\
\text { place in } 2016\end{array}$ & $\begin{array}{l}\text { Plan to take } \\
\text { place in } 2016\end{array}$ \\
\hline Norway & Field testing & Field testing & Field testing & Field testing & - \\
\hline Sweden & $\begin{array}{l}\text { TD control, } \\
\text { testing, shop visit }\end{array}$ & $\begin{array}{l}\text { Information } \\
\text { activities }\end{array}$ & $\begin{array}{l}\text { Information } \\
\text { activities }\end{array}$ & $\begin{array}{l}\text { Information } \\
\text { activities }\end{array}$ & $\begin{array}{l}\text { Planning, } \\
\text { information } \\
\text { activities }\end{array}$ \\
\hline Finland & TD control & - & - & - & - \\
\hline Iceland & - & - & - & - & - \\
\hline Nordic & TD guides & $\begin{array}{l}\text { TD guides } \\
\text { Factsheets }\end{array}$ & $\begin{array}{l}\text { TD guides } \\
\text { Factsheets }\end{array}$ & $\begin{array}{l}\text { TD guides } \\
\text { Factsheets }\end{array}$ & $\begin{array}{l}\text { TD guides } \\
\text { Factsheets }\end{array}$ \\
\hline
\end{tabular}

The Swedish test report dated 2014-03-13 stated that 4 air to air heat pumps have been tested for market surveillance purpose,22 and 3 of them have met the ecodesign and energy labelling requirements with only minor gaps in the technical documentations, but one has declared a too low sound power level. Based on their experience energy efficiency class for colder climate conditions has not been indicated.

The regulation requirements for other types of heat pumps become effective in September 2015, therefore no market surveillance activities have been carried out yet. However, some MSAs such as in Sweden and Denmark are currently drawing up a market surveillance and information activities plan for 2015. A summary status can be found in Table 2 .

The Nordic MSAs are closely collaborating with each other when conducting market surveillance. Draft report for Ecopliant has mentioned the good collaboration between the Nordic MSAs as a practice example. Each country shares with the others the plans for market surveillance each year, to avoid choosing the same products. The results are shared between the countries via email and web service. Sharing of results ensures that non-compliant products found in one country are removed from the market in all Nordic countries.

22 Swedish Energy Agency (2014). Test of air-to-air heat pumps. 
Furthermore the Nordic MSAs collaborated in developing technical documentation guides aimed at improving manufacturer's knowledge of requirements and the quality of the documentations the MSAs receive.

MSA in Denmark has completed an evaluation of the effectiveness of their work in the end of 2014. According to the evaluation results, 5 out of 6 manufacturers have been using the information from the technical documentation guides. ${ }^{23}$ The survey to Nordic SME showed that many heat pump manufacturers are highly interested in the types of products covered by regulations and the existing and coming requirements. ${ }^{24}$ The majority of information of their interests can be found in the factsheets on heat pumps produced in the collaboration of Nordic MSAs. Norway has informed that they have not yet published the guides at the time of writing the report.

\section{Recommendations}

More collaboration between the Nordic MSAs is recommended. Agreement on a common sharing platform and deadline to share the market surveillance plans within the Nordic countries is recommended; the Nordic MSAs could also utilise the sharing platform to spread the results of document control, testing and shop visits as well as experiences learnt.

It is recommended to extend the Danish example of an evaluation of how effective MSAs' work and the information activities have been, after the national authorities have published the guides and factsheets for some time. Questions such as "have the manufacturers been able to use the guides and factsheets" could be added to the follow-up interview of the willing participants of the Nordic SME survey. ${ }^{25}$

It is recommended that the Nordic authorities work together on new information activities such as the Technical Documentation guides and factsheets on regulations.

Cooperation of the Nordic countries when interacting with the Administrative Co-operation (ADCO) working group is recommended. The Nordic countries should work together on the questions to be raised and a collective plan before the ADCO meetings, so the questions can be coordinated to clarify essential issues common to the Nordic conditions.

\footnotetext{
${ }^{23}$ Rapport for undersøgelse af brugernes opfattelse af Sekretariatet for Ecodesign og Energimærkning af Produkters Besvarelse af henvendelser samt brugernes anvendelse af Energistyrelsens vejledninger, January 2015. 24 Preliminary results from survey to Nordic SME conducted by M. Kapanen, January 2015.

${ }^{25}$ Survey to Nordic SME conducted by M. Kapanen, January 2015.
} 


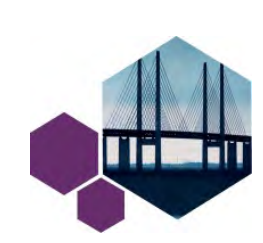

\section{Climate zones and energy labels}

\section{Climate zone}

Climate zone is one important aspect of the energy labels for heat pumps. Information on the energy label either directly refers to a specific climate zone or is calculated based on the conditions of one. The European Reference for climate conditions divides Europe geographically into three zones: colder, average and warmer climate conditions. The simplest method to determine the climate zone of a country is to consult the map of climate zones, see Figure 6. A similar map is usually shown on the energy label of individual product according to relevance. It can be seen from the map that Denmark is located in "average" climate zone, whereas Norway, Sweden, and Finland are located in "colder" climate zone. Iceland is in "colder" climate zone though not shown on Figure 6.

Figure 6. European map of climate conditions

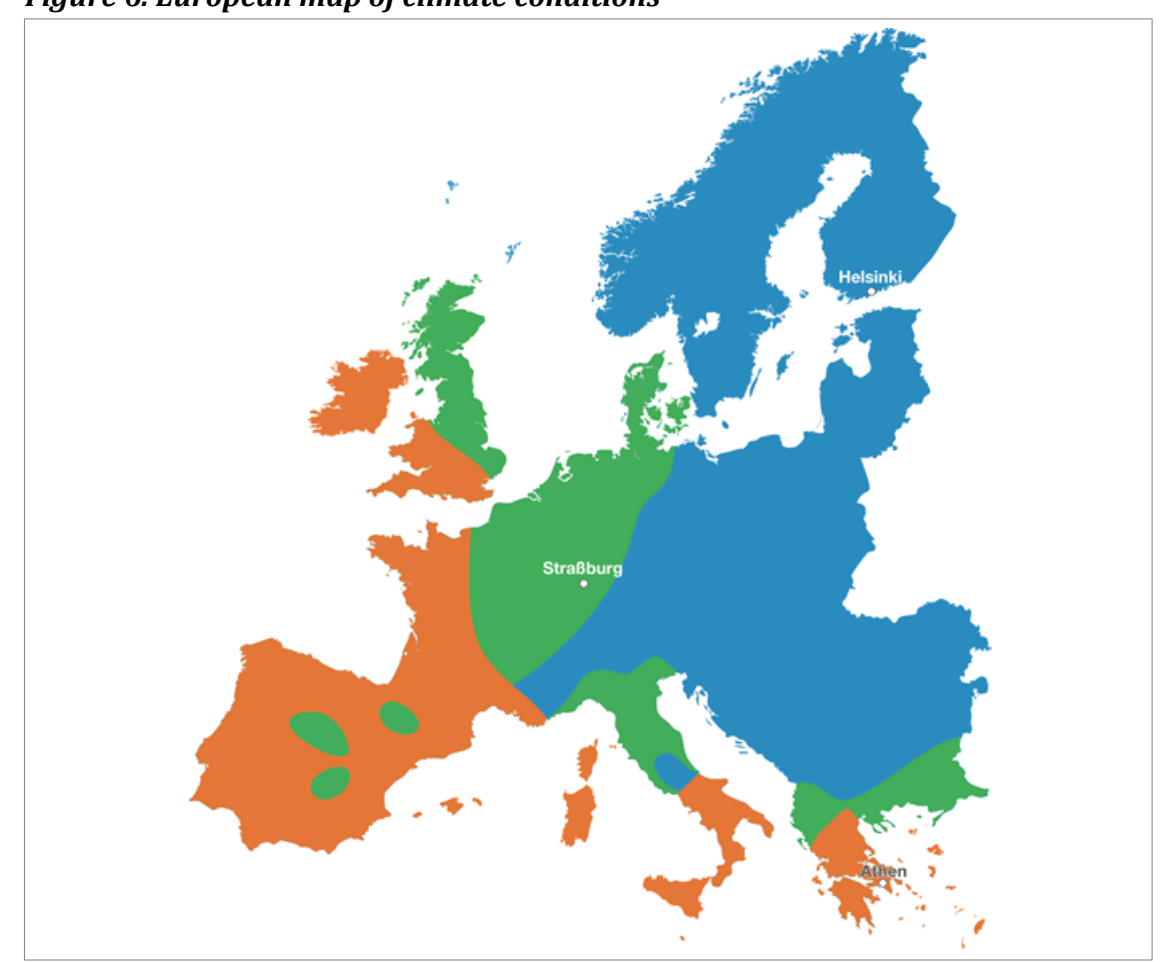




\section{Energy labels}

The energy labels are required by the energy labelling regulations. For different types of heat pumps and package products, they display different information. As shown in Table 3, it is usually mandatory to indicate information for average climate conditions, but for colder climate conditions it is often optional or no indication at all on the label.

On the energy labels of air to air heat pumps, it is mandatory to indicate the energy efficiency class SCOP for heating and SEER for cooling, rated output and annual energy consumption for average climate conditions, but it is also possible to indicate the information for colder or warmer climate conditions. However this is only optional. Examples of air to air heat pump energy labels can be seen in Figure 7.

\begin{tabular}{|c|c|c|c|c|c|}
\hline Information & Air to air HP & $\begin{array}{l}\text { HP Space } \\
\text { heaters }\end{array}$ & $\begin{array}{l}\text { HP Combina- } \\
\text { tion heaters }\end{array}$ & $\begin{array}{l}\text { HP Water } \\
\text { heaters }\end{array}$ & Packages \\
\hline SCOP - average & Mandatory & - & - & N/A & - \\
\hline SCOP - cold & Optional & - & - & $\mathrm{N} / \mathrm{A}$ & - \\
\hline Efficiency Class - average & Mandatory & Mandatory & Mandatory & Mandatory & Mandatory \\
\hline Efficiency Class - cold & Optional & - & - & - & - \\
\hline Rated output - average & Mandatory & Mandatory & Mandatory & - & - \\
\hline Rated output - cold & Optional & Mandatory & Mandatory & - & - \\
\hline $\begin{array}{l}\text { Annual energy/fuel } \\
\text { consumption - average }\end{array}$ & Mandatory & - & - & Mandatory & - \\
\hline $\begin{array}{l}\text { Annual energy/fuel } \\
\text { consumption - cold }\end{array}$ & Optional & - & - & Mandatory & - \\
\hline
\end{tabular}

Based on the experiences of market surveillance of air to air heat pumps in Denmark, Sweden and Finland, information for colder climate conditions are not shown on the energy labels for air to air heat pumps, even though it is possible to be indicated. This is potentially a problem, as the Nordic consumers may be misled by the higher efficiency, rated power and lower energy consumption for average climate, at the same time consumers are not getting the most realistic information if they live in colder conditions. 
Figure 7. Air to air heat pump (air conditioners) with heating and cooling (left), and heating only (right) energy labels
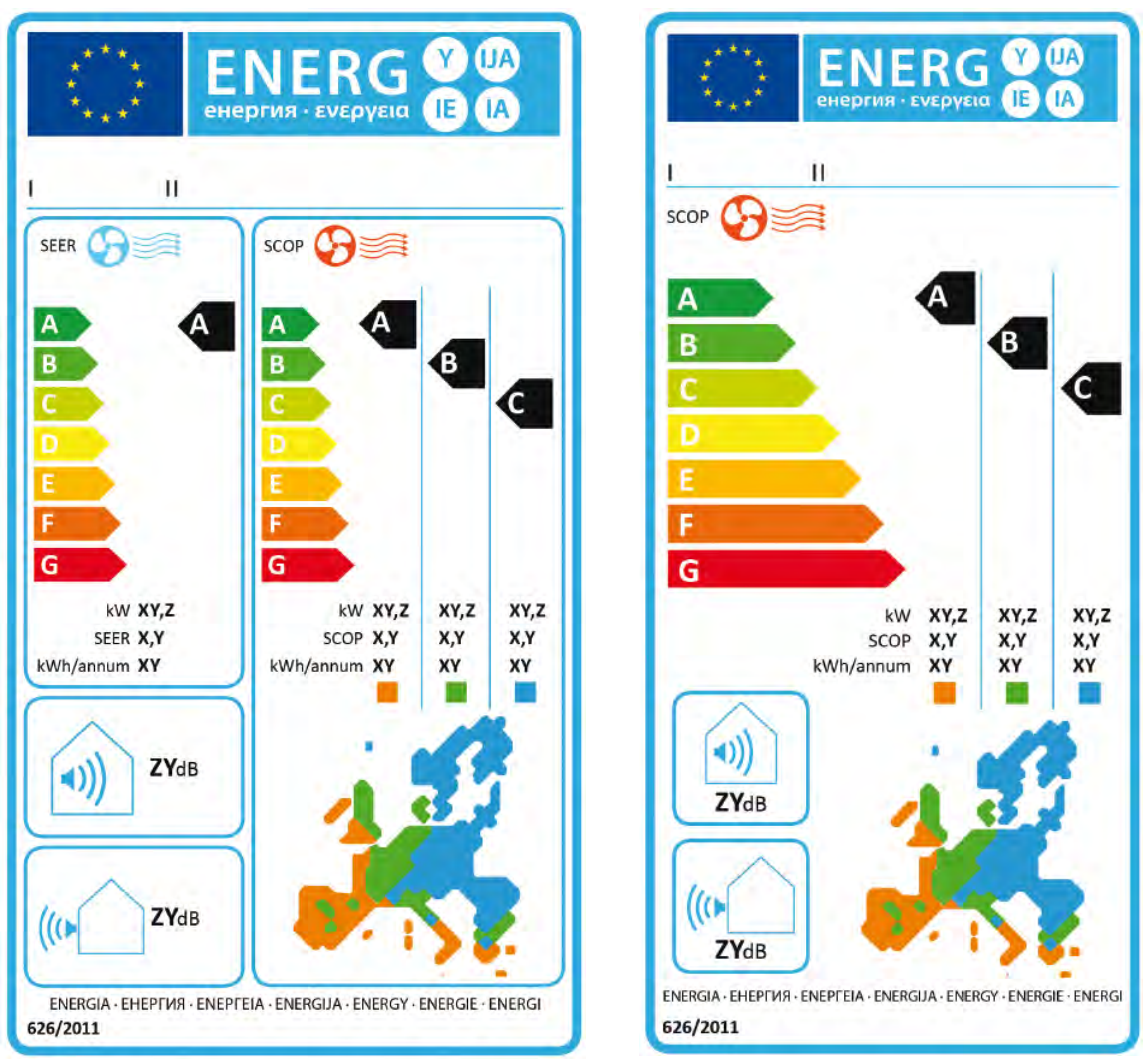

For other types of heat pumps and package products, there is no indication of efficiency class for colder climate conditions on the label. All efficiency classes are indicated for only average climate conditions.

Examples of energy labels for the HP space heaters, HP combination heaters and HP water heaters can be seen in Figure 8. On the labels the climate zones are shown with tree different shades of blue. Using the colour keys, the rated heat output in $\mathrm{kW}$ can be found on the label for average, colder and warmer climate conditions, and this information is mandatory for space heaters and combination heaters.

The energy label for heat pump water heater is very similar to combination heaters with one exception that annual electricity consumption in $\mathrm{kWh}$ and annual fuel consumption in GJ are mandatory to display for average, colder and warmer climate conditions. 
Figure 8. Heat pump space heater, heat pump combination heater, and heat pump water heater energy labels (left to right)

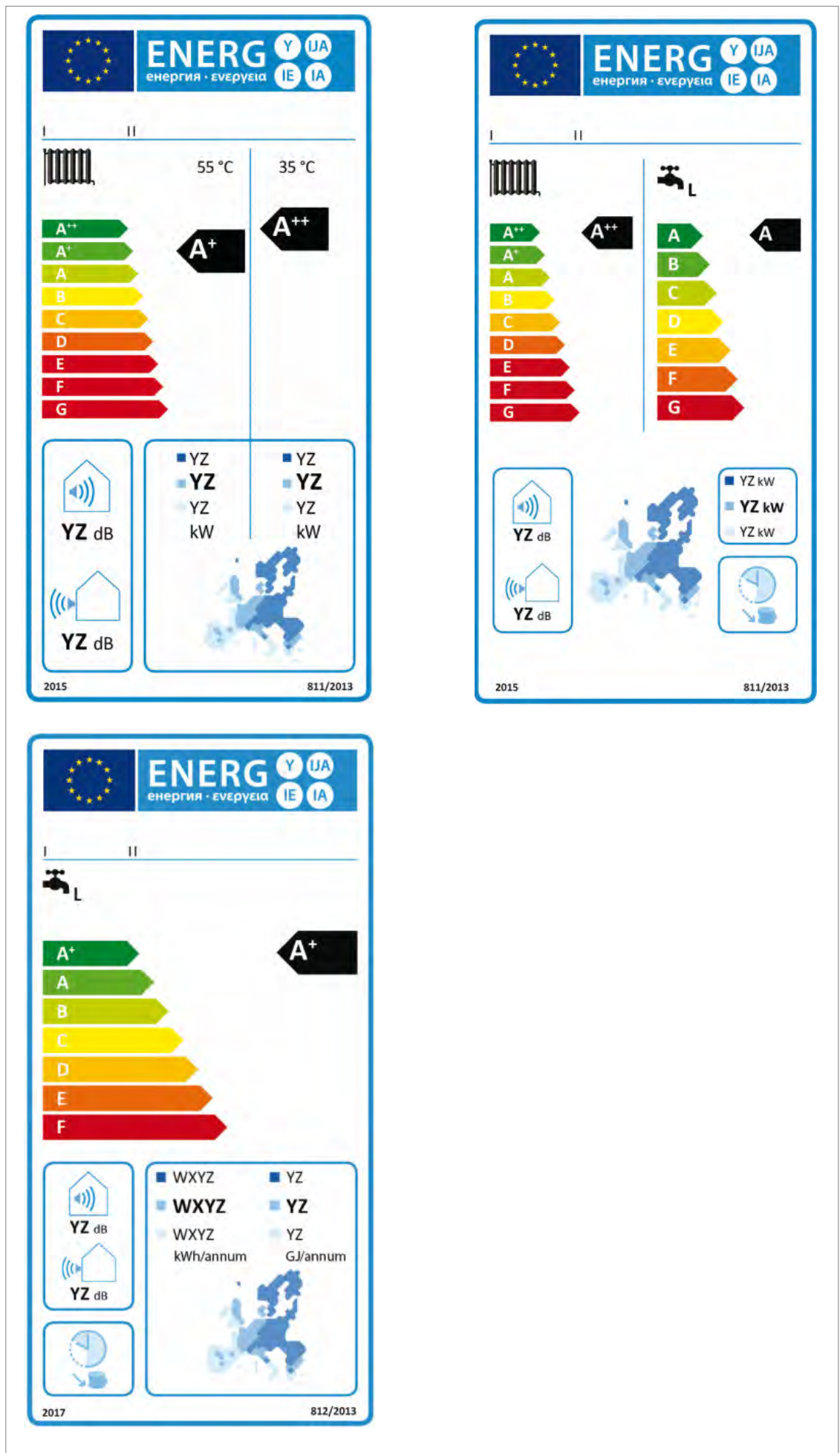


On the energy label for packages of heat pump sold with temperature controls, solar device or supplementary heater, it is required to indicate an overall energy efficiency class of the package, energy efficiency class of the heater, and indicate other products sold in combination. The overall energy efficiency is calculated based on average climate conditions, but there is no indication of which climate zone the efficiency applies to.

Figure 9. An example from the DEA's website for a package of heat pump with temperature controls (left), and energy label for packages of heat pump water heater with solar device and hot water storage
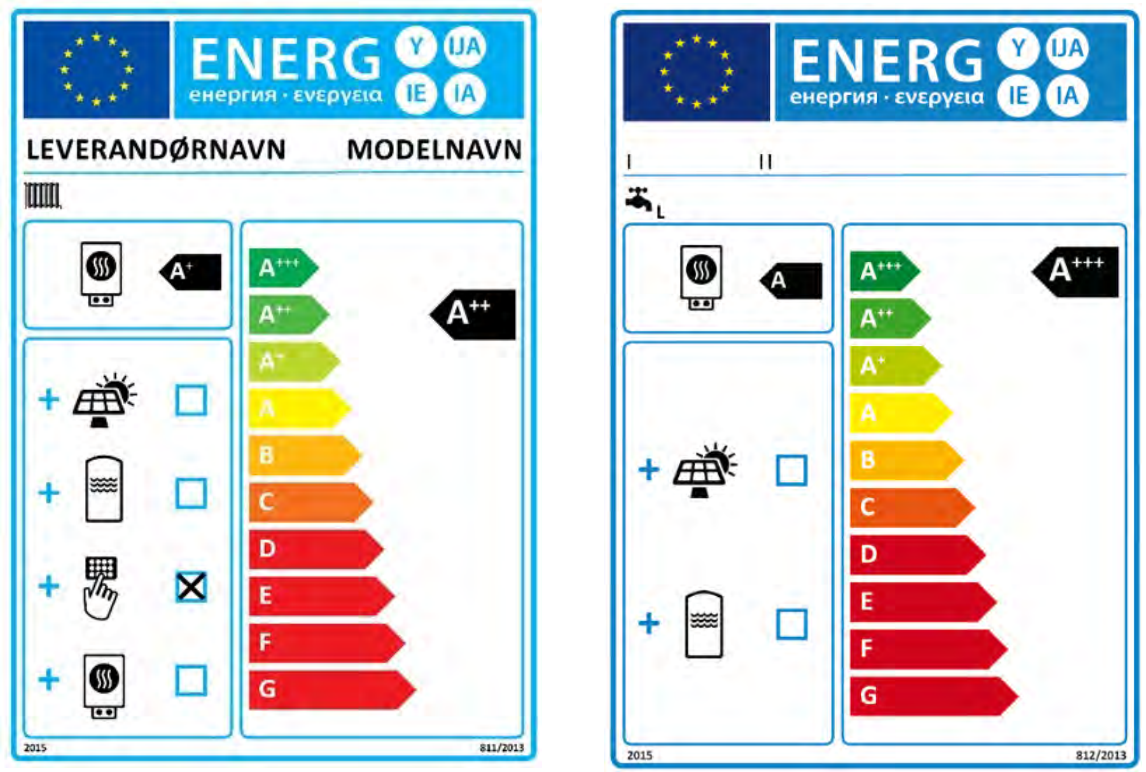

\section{Product fiche and ecodesign requirements}

For HP space heaters, HP combination heaters, HP water heaters and packages, the missing efficiency class for colder climate is a minor problem, as this information can be found in the product fiche. Energy labelling regulations on heat pumps also include information requirements for product fiche. Seasonal space heating efficiency and water heating efficiency under colder and warmer climate conditions are required to be provided in the product fiches of the HP space heaters, HP combination heater and HP water heaters. Packages with heat pump space heaters and combination heaters, the difference between seasonal space heating efficiency under average and colder climate conditions should be also indicated in percentages. For product fiche of air to air heat pumps, SCOP is not required, therefore it is even more crucial that manufactures show efficiencies of all three climate zones on the labels. 


\begin{tabular}{|c|c|c|c|c|c|}
\hline Information in fiche & Air to air & $\begin{array}{l}\text { Space } \\
\text { heaters }\end{array}$ & $\begin{array}{l}\text { Combination } \\
\text { heaters }\end{array}$ & $\begin{array}{l}\text { Water } \\
\text { heaters }\end{array}$ & Packages \\
\hline SCOP - cold & - & - & - & - & - \\
\hline $\begin{array}{l}\text { Seasonal space heating } \\
\text { efficiency - cold }\end{array}$ & NA & Mandatory & Mandatory & NA & Mandatory* \\
\hline $\begin{array}{l}\text { Water heating efficiency } \\
\text { - cold }\end{array}$ & NA & NA & Mandatory & Mandatory & Mandatory \\
\hline Rated output - cold & - & Mandatory & Mandatory & - & - \\
\hline $\begin{array}{l}\text { Energy/fuel consumption } \\
\text { - cold }\end{array}$ & - & Mandatory & Mandatory & Mandatory & - \\
\hline
\end{tabular}

*For packages with space heaters and combination heaters, only the difference between seasonal space heating efficiency under average and colder climate conditions in \%.

Ecodesign regulations on heat pumps also include information requirements on manufacturer's websites, user manual and technical documentation. However, heat pump's efficiency under colder climate conditions is not required for any of them.

\section{Nordic actions}

The Nordic countries have already taken actions regarding the issues that could potentially arise from the new regulations on heat pumps. A series of Technical Documentation guides and factsheets on the new regulations on the different types of heat pumps have been developed to help suppliers' understanding.

There are some questions regarding the regulation that are still uncertain, for example, if the heat pump should have its own energy label within the package product and how to handle the package label, sometimes known as the installer labels. Swedish Authority SEA has enquired a number of questions about energy labels of heat pumps, including the ones mentioned above to the Commission, once the questions have been clarified, the answers should be shared within the Nordic countries, who will agree on a common understanding regarding these issues.

As mentioned previously, Denmark has developed information brochures to installers and contractors about the new energy labelling of heat pumps. Brochure explains graphically how to understand package labels and icons on the labels. These brochures can be distributed to the certified installers and installer associations etc. 


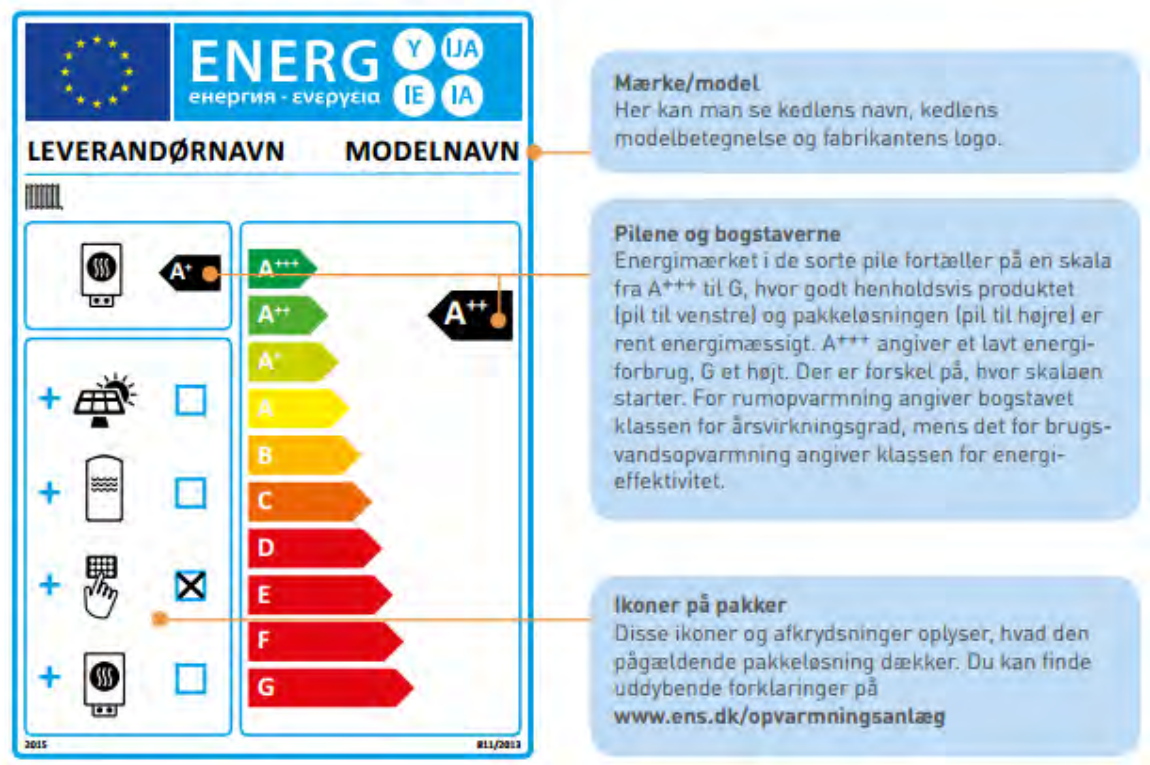

\section{Recommendations}

It is essential that heat pumps are marketed with the information suited for the actual operation conditions, so that the consumers can choose the right heat pump. It is recommended to encourage the manufacturers of air to air heat pumps to display the efficiency class for colder climate as well as average climate zones on the energy labels in the Nordic countries. This could be achieved via dialog with the industry associations and manufacturers.

For HP space heaters, HP combination heaters, HP water heaters and packages, the efficiency for colder climate conditions can be found in product fiche, therefore it is recommended to educate the installers and consumers to look for/request the product fiche when purchasing a heat pump via information activities.

Information efforts could be made to educate the consumers about different climate zones, and how they affect the energy efficiency of products and highlight importance of efficiency under colder climate

${ }^{26} \mathrm{http} / / /$ www.ens.dk/sites/ens.dk/files/forbrug-besparelser/apparater-produkter/energimaerkningapparater-produkter/installatoerer/hvad_staar_der_paa_energimaerkerne-_ikonforklaring.pdf 
conditions. Information can be disseminated via websites, brochures and guides.

The Nordic countries could carry out an investigation of the effects of climate zones on energy efficiency class and usefulness of information on the energy label when the information does not correspond to the actual climate zone where the heat pump is installed. This could involve testing of a number of heat pumps in different climate conditions. The test results could form a strong foundation for issues to be raised upon the revision of regulations.

When the regulations on heat pumps should be revised, the Nordic countries should work together to introduce requirements on additional information. Efficiency class for the all 3 climate conditions should be shown on energy label for all heat pump types, and added to technical documentation, product fiche and information on websites.

As mentioned, Nordsyn has developed factsheets to suppliers and dealers about the new energy labelling and ecodesign requirements for heat pumps. These factsheets should be supplemented by additional guides on how to use the package labels in combination with other labels, the responsible party for the package label and the market surveillance for these products, once the Nordic countries receive clarifications.

Nordic authorities could extend the Danish example by developing Nordic guides targeted at installers and salesmen to inform them about energy labels and the contents on the label. Based on the results of the survey to Nordic SME, this type of information is highly preferred in both English and native languages. 


\section{'s \\ 6. The Danish Energy Agency's heat pump list - "Varmepumpelisten"}

As an effort to promote energy efficient heat pumps, since 2013 the DEA has launched a digital tool for consumers. ${ }^{27}$ "Varmepumpelisten" recommends the best heat pumps on the Danish market, ${ }^{28}$ and all heat pumps on the list are compliant with Danish and EU legal requirements as well as tested by an independent laboratory. There are currently 235 heat pumps in total divided into 3 types: air to air, air to water and liquid to water heat pumps, and there are ongoing admissions to the list.

Half of the manufacturers on "Varmepumpelisten" come from the Nordic countries, mainly Denmark, such as Heat Saving, Metro Therm, Klimadan, Vølund etc. A few manufacturers are from Sweden such as CTC and Thermia, but the largest Swedish manufacturer of heat pump, Nibe is not on the list. There are also a range of heat pumps from other European countries, as well as from global manufacturers who have representatives in Europe.

The heat pump list is supported by the heat pump association in Denmark, "Varmepumpefabrikanterne". The heat pump industry had been involved in the process of developing the admission requirements; therefore this list is fully backed by the industry.

To be included in the list, the manufacturers shall contact to the Danish MSA. The manufacturers need to provide supporting documentations and test reports from an accredited laboratory that show the product has met the admission requirements set by the DEA. Once the documentation are evaluated and confirmed, the product will be displayed on the list. Although it is free of charge to be on the list, the manufacturers

\footnotetext{
${ }^{27}$ http://ing.dk/artikel/nu-kan-du-sammenligne-varmepumpers-effektivitet-over-en-hel-dansk-vinter163728

${ }^{28} \mathrm{http} / / /$ sparenergi.dk/forbruger/vaerktoejer/varmepumpelisten
} 
however are eligible to pay for the costs of the tests. A test from an accredited laboratory can cost up to DKK 55,000.

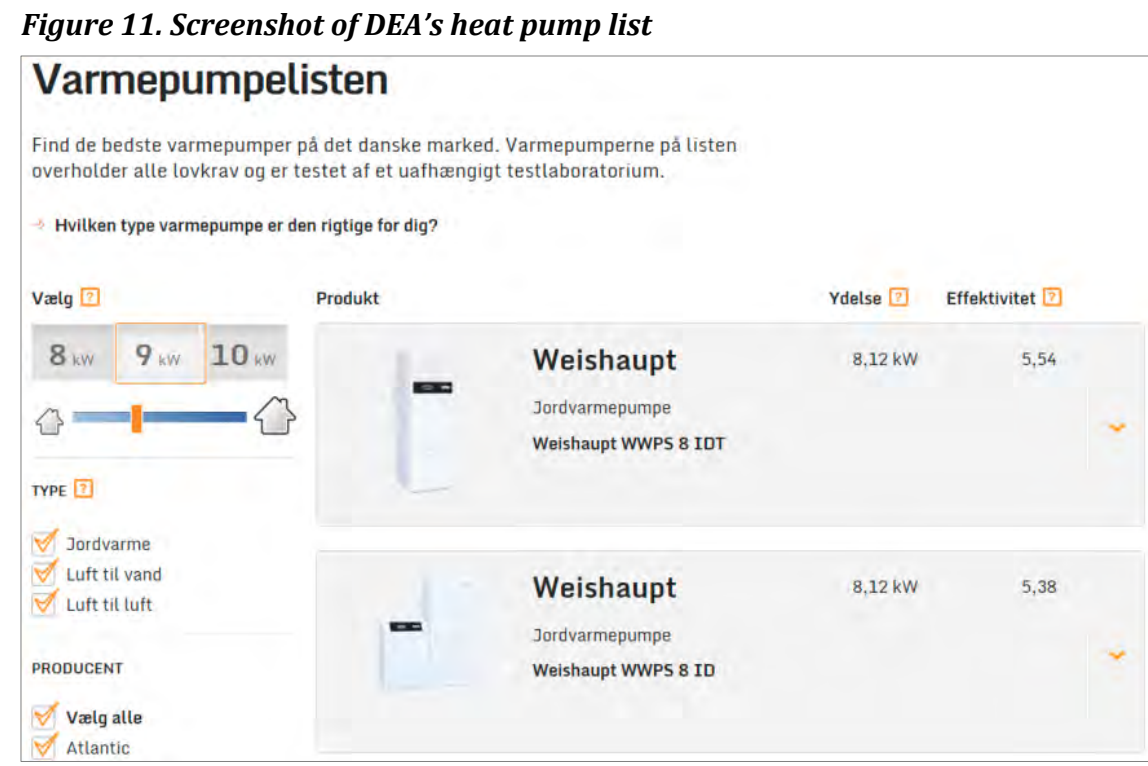

When the requirements are revised the manufacturer will be notified about the changes 4 months in advance. The manufacturers should supply new documentation before the deadline, otherwise the product will be removed from the list.

"Varmepumpelisten" is influential in the heat pump industry in another angle, as the consumers can only receive subsidies for installing a heat pump if the heat pump is on the list. There has been many different subsidy schemes to promote the use of heat pumps on the list. Currently the consumers can receive "subsidies" in the form of getting payment from electricity companies for energy savings by replacing an old oilfired boiler with a heat pump, but only if they choose to install one of the heat pumps on the "Varmepumpelisten". As heat pump systems are expensive, consumers are very interested in receiving subsidies. Therefore many manufacturers are eager to be present on the list.

The work behind managing the list, administration and admission is equivalent to the tasks of one person on fulltime employment, and occasionally supported by a technical expert from the DTI. In order to promote the list, the DEA has reached out to many relevant websites and manufacturers of heat pumps. Links to the list is now added on many websites about heat pump or about obtaining subsidies for energy im- 
provements. Hence, "Varmepumpelisten" is currently the most visited site of DEA.

Over the years, it is observed by the Danish heat pump experts that the heat pumps with poorest performances and quality are disappeared from the market gradually. This development could be driven by the admission requirements of "Varmepumpelisten" together with the EU regulations.

\section{Recommendations}

Heat pump lists are considered to be very useful tools to improve the quality of heat pumps and create consumer confidence.

It is recommended that all heat pump lists in the future as far as possible are based on the measurement and calculations methods used in the ecodesign and energy labelling regulations. Harmonisation of measurement methods etc. will reduce the manufacturer's cost for application. If the requirements are harmonised, a heat pump added to one list can easily be automatically added onto the other lists.

It should be considered to require that lists when relevant shows the energy efficiency class etc. of the heat pump in cold climate zone. Furthermore it should be considered to set a maximum value for the sound power level for indoor and outdoor unit. More about sound power level in next section.

As many Nordic manufacturers have shown interests in the Danish heat pump list, cooperation on a common Nordic list could be considered. A common list could operate alongside national lists, as long as it builds on harmonised measurement and calculations methods. The admission requirements should include ambitious requirements and could cover more areas than the regulations/national lists and issues of special Nordic interests (such as colder climate zone). One important principle should be that the manufacturers only need to apply once. A first step could be to discuss the possibility with Nordic heat pump associations and relevant stakeholders. 



\section{Sound power level}

Consumers are often interested in the sound level when purchasing a product which would be placed indoor or outdoor if placed in proximity of windows, door or commonly used area. Sound power level gives an indication of how loud a machine/product is in a numerical and logarithmic scale.

It is mandatory to declare the sound power level on the energy labels for all types of heat pumps, except for packages, as shown in Figure 7 to Figure 9. Even though the sound level is declared on the label, it is rather abstract to imagine how loud the sound is. Consumers would need to be familiar with sound level scale beforehand.

Ecodesign regulations often identify benchmarks regarding the best available technology on the market at the time of entry into force of the regulation. Some of the regulations on heat pumps include benchmarks with regard to sound power level.

There is no benchmark identified by the ecodesign regulation for air to air heat pumps. Regulations on HP space heaters, HP combination heaters and HP water heaters identify benchmarks with regard to the outdoor sound level, however there is no benchmark identified for indoor sound power level. When comparing the outdoor sound power level limits set by ecodesign requirements to the benchmarks, the limits seems unambitious. 
Table 5. Ecodesign requirements for maximum sound power level ( $\left.L_{W A}\right)$ by heat pumps and benchmarks for outdoor unit

\begin{tabular}{|c|c|c|c|c|}
\hline $\begin{array}{l}\text { Heat pump } \\
\text { type }\end{array}$ & Rated capacity and output & $\begin{array}{r}\text { Ecodesign } \\
\text { requirements for } \\
\text { indoor unit, } d B\end{array}$ & $\begin{array}{r}\text { Ecodesign } \\
\text { requirements for } \\
\text { outdoor unit, dB }\end{array}$ & $\begin{array}{r}\text { Benchmark } \\
\text { Outdoor, dB }\end{array}$ \\
\hline \multirow[t]{2}{*}{ Air to air HP } & Rated capacity $\leq 6 \mathrm{~kW}$ & 60 & 65 & - \\
\hline & $\begin{array}{l}\text { Rated capacity }>6 \mathrm{~kW} \\
\text { and } \leq 12 \mathrm{~kW}\end{array}$ & 65 & 70 & - \\
\hline $\begin{array}{l}\text { HP space } \\
\text { heaters }\end{array}$ & Rated heat output $\leq 6 \mathrm{~kW}$ & 60 & 65 & 39 \\
\hline \multirow{3}{*}{$\begin{array}{l}\text { HP combination } \\
\text { heaters } \\
\text { HP water } \\
\text { heaters }\end{array}$} & $\begin{array}{l}\text { Rated heat output }>6 \mathrm{~kW} \\
\text { and } \leq 12 \mathrm{~kW}\end{array}$ & 65 & 70 & 40 \\
\hline & $\begin{array}{l}\text { Rated heat output }>12 \mathrm{~kW} \\
\text { and } \leq 30 \mathrm{~kW}\end{array}$ & 70 & 78 & 41 \\
\hline & $\begin{array}{l}\text { Rated heat output }>30 \mathrm{~kW} \\
\text { and } \leq 67 \mathrm{~kW}\end{array}$ & 80 & 88 & 67 \\
\hline
\end{tabular}

Even though there is a test standard for measuring noise, there is an uncertainty in how to measure the sound levels, which make this parameter difficult to have market surveillance on.

The Danish requirements for sound power level as stated in BR10 are presented in Section 2.2. The DEA has developed a guide on how to get control of the noise level during installation of air to water heat pumps. ${ }^{29}$ It depends highly on the choice of a suitable heat pump and a feasible location to place the heat pump so the noise level can be minimized. The guide is combined with an online calculation tool on DEA's website. The calculation tool can be used to illustrate the consequence of noise level in the surroundings. ${ }^{30}$

The Norwegian Building Regulations also have requirements on sound power levels, the outdoor requirement during the night is maximum $35 \mathrm{~dB}$, and there is no indoor requirement. ${ }^{31}$ "The Norwegian Association Against Noise" has published documents about heat pump noise levels. ${ }^{32}$ The document states comprehensive information about sound power level and the rule of thumb when placing heat pumps in relation to noise, however they are quite technical and can be difficult for consumers to read.

${ }^{29}$ Styr på støjen - en guide til installation af luft til vand varmepumper. Udarbejdet for Energistyrelsen, december 2012. Grontmij.

$30 \mathrm{http}$ ///www.ens.dk/forbrug-besparelser/byggeriets-energiforbrug/varmepumper/stojberegner

31 Kjøpsveileder luft/luft-varmepumpe - En veileder fra Enova og Miljødirektoratet, ENOVA, 2014.

32 http://www.stoyforeningen.no/Nyheter/Varmepumper 


\section{Recommendations}

Upon the revision of energy label, the Nordic countries should work together on recommendation to include an A to G scale of sound power levels on the energy label like the scales used for example for cleaning performance on the energy label for vacuum cleaners and grease filtering efficiency on the label for range hoods.

Figure 12. A-G scales used on the label for range hoods to illustrate the products performance with regard to hydraulic efficiency, lighting efficiency and grease filtering efficiency

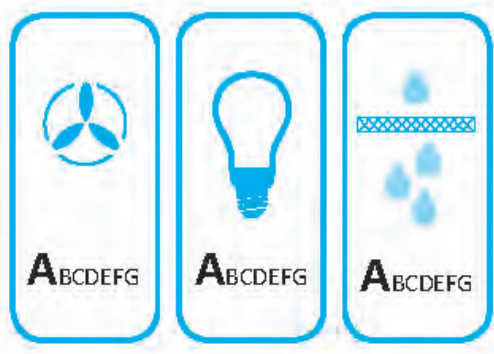

Figure 13. Proposal of new indication of sound power level on the label

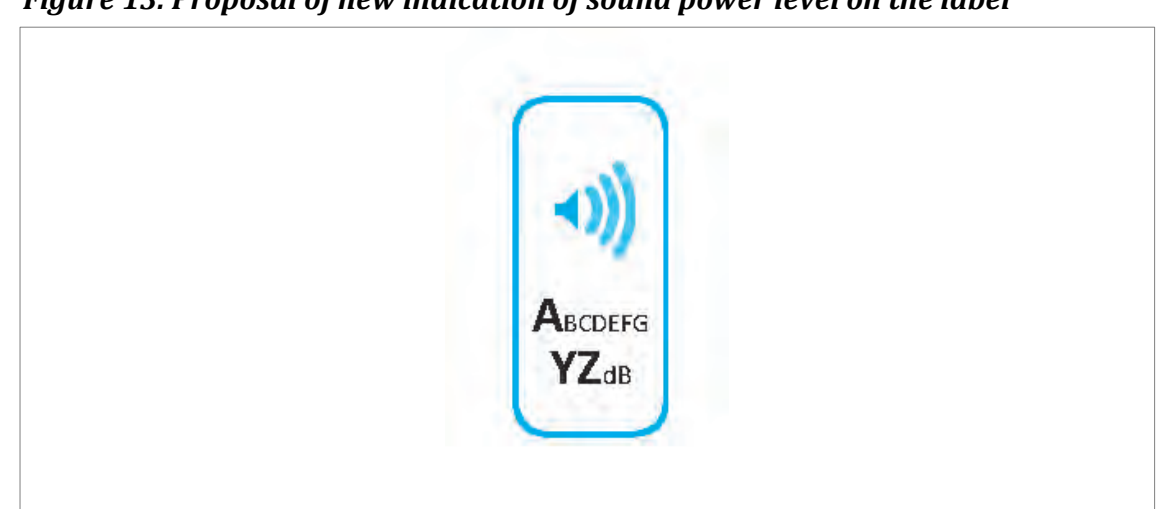

The Nordic countries can work together to introduce more ambitious requirements for sound power level when the Ecodesign regulations should be revised. It is recommended to prepare well in advance so there is good data support for what level of sound power is achievable. The first revision will take place in 2017 for regulation 2012/206/EU on air to air heat pumps.

In the meantime, the Nordic countries should develop guides to educate consumers about noise and how to reduce it and evaluate the level 
of loudness in an easy-to-read manner. The guides can be inspired by DEA's guides and online calculation tool.

The existing information about noise level published by national authorities could be revised and re-written in simple and non-technical language, so the consumers can easily understand.

Requirements should be added in the national building regulations for sound power level of outdoor unit in proximity of outdoor living area and neighbour grounds, if there is not similar requirement currently.

Sound power limits should be added to the admission requirements of any national arrangements to promote heat pumps, e.g. "Varmepumpelisten" and P-marking. If a Nordic heat pump list to be developed, it could be one of the minimum admission criteria to meet, so the products not only perform efficiently but also at an acceptable sound level. 


\section{Smart tariffs (Off-Peak tariffs for load shifting)}

Off-Peak tariffs or Time of Use (TOU) metering aims to shift the peak load to off-peak periods, so a more uniformed usage of electricity is achieved throughout the day.

One argument against the use of heat pumps is that they consume the most electricity during peak times when all other electrical appliances are operating. This gives spikes in electricity demand and difficulty for the grid to cope.

The DEA and Energinet.dk have carried out a heat pump project involving 300 homeowners. ${ }^{33}$ The project has demonstrated preliminary conclusions that even during very cold winter period, the electricity consumption by heat pumps in these 300 homes can be successfully shifted to low peak or periods where there is a lot of wind generated electricity in the grid.

The project concludes that load shifting works well in high thermal mass and well insulated buildings, or with a large buffer tank to avoid many start/stop of the heat pump and store heat in periods where heat pumps is not operating.

According to research by University of Strathclyde, UK, ${ }^{34}$ using a buffer tank large enough to provide for the household's heat demand via heat pumps in off-peak periods could potentially lead to higher energy consumption, therefore sometimes it leads to larger electricity bills despite off-peak tariffs (if the off-peak rebate is too low). Although electricity load can be shifted, the overall energy consumption would increase.

It should be noted that the research result is based on simulations and uncertainties can be expected. As the project and research are conducted in Denmark and the UK respectively, degree days would differ from the

\footnotetext{
${ }^{33} \mathrm{http}$ ///energinet.dk/DA/FORSKNING/Energinet-dks-forskning-og-udvikling/Sider/Fra-vindkraft-tilvarmepumper.aspx

${ }^{34} \mathrm{https}$ ///www.academia.edu/6306064/PERFORMANCE_ASSESSMENT_OF_TARIFF-BASED_AIR_SOURCE_ HEAT_PUMP_LOAD_SHIFTING_IN_A_UK_DETACHED_DWELLING_FEATURING_PHASE_CHANGEENHANCED_BUFFERING
} 
other Nordic countries in colder climate conditions, but it is worth considering the environmental benefits of utilising for instance a larger amount of wind generated electricity, and the efficiency benefits that comes with a steadier load profile. However it is crucial that Off-Peak tariffs are low enough to generate savings for each household, otherwise the environmental benefits alone may not attract a large numbers of interests.

In Denmark - for example, under IdeEL ${ }^{35}$ agreement from electricity supply company Modstrøm, the consumers pay for energy consumption on an hourly basis. The tariff is usually cheaper during the night; approx. DKK 0.35/kWh between 00:00-06:00, and it steadily increases throughout a day to peak at around DKK 0.75/kWh in the evening 18:00-23:00. But under this agreement the consumers pays nothing for the energy consumed during the night, saving the cost for approx. $14 \%$ of an average household's consumption. A household with heat pumps aiming to shift their consumption for heating to off-peak periods could save up more under this agreement. See Figure 14.

Figure 14. Danish example of smart tariffs - IdeEL from Modstrøm

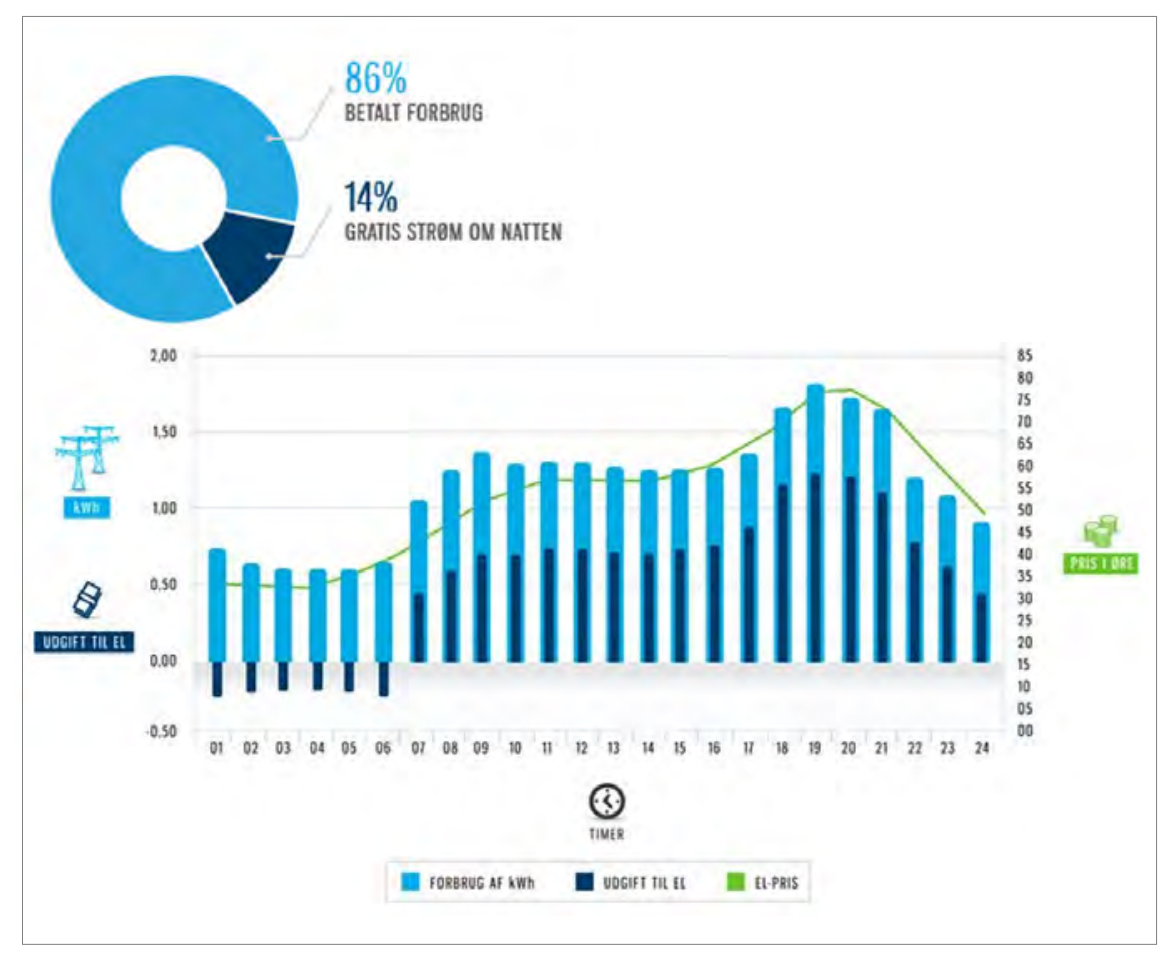

${ }^{35}$ https://www.modstroem.dk/privat/produkter/ideel 


\section{EU Smart Appliances preparatory study}

From October 2014, the European Commission has started an ecodesign preparatory study regarding smart appliances, with focus also on smart grid. Smart appliances and smart grid give the control to the supply side, whereas smart tariffs give the control to the demand side.

A smart appliance' operation can be intervened by an electricity supply company, or an aggregator (organisation who helps balance the demand with the supply), e.g. energinet.dk in Denmark. The aggregator can for example turn off the smart appliance (such as heat pump) for a period of time when the demand is peaking and would need to quickly start a generator if the demand is not reduced. The start-up process can be very energy consuming and inefficient if the generator is only needed for a short time.

A smart appliance could also mean that the appliance turns itself on and off according to the energy prices. Many heat pumps are already labelled "smart grid ready" in Germany, although there is no test standards for this at the time of writing this report. Demand shift with heat pumps would be much easier once the technology and standards for smart appliances have been established. In the meantime, smart tariffs can act as a manual transition, and the conscious choice from consumers is therefore needed.

\section{Recommendations}

If the Nordic countries want the consumers to invest in heat pumps systems with possibility to turn off the pump during peak load periods, the first step will be to ensure that the consumers have economic incentives to invest in such systems.

It will normally be possible to turn off all heat pumps during shorter periods (it only requires suitable control systems). But if a more substantial shift from periods with high peak load to low peak load is the goal, there are certain requirement for the house/system and the possibility for heat storage (thermal mass or buffer tank).

It is important that the rebate during low peak periods takes into account that the overall energy consumption for the heat pump will increase due to the increased heat losses from heat storages etc.

The next step will be dissemination of information to the consumers about possible technical solutions and economic consequences. As it is a long term investment for the consumers it is important that they could have confidence in energy prices and price reduction during low peak periods. An idea could be that electricity supply companies offer the consumers to enter into longer term agreements with the electricity supply company about favourable tariffs during low peak periods (rebates). 
Nordic countries can encourage the electricity companies to provide such offers as it is beneficial also for the supplier if there are fewer peaks in the demand.

The information should include details about which houses are suitable for shift to low peak periods. What is the requirement for thermal mass, how large should the buffer tank be to cover the heat demand be etc.

Information campaign with "nudging" elements can often be useful when attempting to change consumer's behaviour. Presenting information in the correct way has shown promising effects in persuading consumers to choose the environmental but temporarily costly or inconvenient options. Norway completed a pilot project where the typical energy cost for washing machine was stated clearly in Norwegian Kroner beside the energy class, the project concluded that consumers chose higher energy class, because the extra information adjusted their purchasing bias by shifting their focus on the long-term gain instead of large initial cost. ${ }^{36}$

It could be also possible to get the consumers to shift energy demand by showing the amount of cost savings being lost. It is therefore recommended that the Nordic countries carry out a pilot project of researching on what methods of "nudging" or information presentation works for people in the Nordic countries or in each country itself in terms of shifting demand via heat pumps. In order to support the information campaign, calculation for typical household savings etc. in each Nordic country should be made.

It is also recommended that the Nordic countries follow the progress of preparatory study for smart appliances and work together to submit inputs and comments from a Nordic point of view.

${ }^{36}$ Energistyrelsen (2013). Brug af nudging til at øge energieffektivisering. 


\section{Certified Installers}

Consumers are not allowed to install heat pumps themselves, and have little knowledge about the upcoming energy and package labels and what they mean. It is therefore important to have competent installers who can help the consumers to choose and install the right heat pump solutions.

As of Article 14 of the Renewable Energy Sources Directive 2009/28/EC, the EU member states should have introduced certification of installers for heat pumps, biomass and solar cells by the end of 2012 .

According to the directive the training leading to installer certification or qualification shall include both theoretical and practical parts. At the end of the training, the installer must have the skills required to install the relevant equipment and systems to meet the performance and reliability needs of the customer, incorporate quality craftsmanship, and comply with all applicable codes and standards, including energy and eco-labelling.

Accredited training programmes should be offered to installers with work experience, and in the case of heat pumps installers have training as a plumber or refrigeration engineer and have basic electrical and plumbing skills (cutting pipe, soldering pipe joints, gluing pipe joints, lagging, sealing fittings, testing for leaks and installation of heating or cooling systems) as a prerequisite.

The theoretical part of the heat pump installer training should give an overview of the market situation for heat pumps and cover geothermal resources and ground source temperatures of different regions, soil and rock identification for thermal conductivity, regulations on using geothermal resources, feasibility of using heat pumps in buildings and determining the most suitable heat pump system, and knowledge about their technical requirements, safety, air filtering, connection with the heat source and system layout. The training should also provide good knowledge of any European standards for heat pumps, and of relevant national and Community law. The installer should demonstrate the following key competences: 
- a basic understanding of the physical and operation principles of a heat pump, including characteristics of the heat pump circle: context between low temperatures of the heat sink, high temperatures of the heat source, and the efficiency of the system, determination of the coefficient of performance (COP) and seasonal performance factor (SPF)

- an understanding of the components and their function within a heat pump circle, including the compressor, expansion valve, evaporator, condenser, fixtures and fittings, lubricating oil, refrigerant, superheating and sub-cooling and cooling possibilities with heat pumps

- the ability to choose and size the components in typical installation situations, including determining the typical values of the heat load of different buildings and for hot water production based on energy consumption, determining the capacity of the heat pump on the heat load for hot water production, on the storage mass of the building and on interruptible current supply; determine buffer tank component and its volume and integration of a second heating system.

\section{Certified installers in Denmark}

In Denmark, VE-godkendelsesordningen is launched by DEA to certify installers for biomass, solar cells and heat pumps. An electrical or building services authorisation by installation association TEKNIQ is prerequisite for the company and the individuals to be certified by the program.

Although it is voluntary to be certified, the companies that choose to certify any of their employees for one or more technologies would need to demonstrate their competences and education live up to the requirements of the certification. Requirement for education is described in the Danish order: "Bekendtgørelse om en godkendelsesordning for virksomheder der monterer små vedvarende energianlæg". ${ }^{37}$

The certification takes into consideration of energy efficiency aspects. In order to be certified installer for heat pumps the company shall have at least one VE-educated employee, that have the theoretical competences required in the order mentioned above (is similar to the theoretical competences mentioned in the directive), have participated in relevant education and have passed an examination. The VE-educated employee is not necessarily an installer, but people with more general and

${ }^{37}$ https://www.retsinformation.dk/Forms/R0710.aspx?id=158160\#Kap3 
theoretical skills, who can assist the installer and ensure the quality of the companies work including information to consumers, compliance with applicable codes and standards, including energy and eco-labelling, correct dimensioning etc.

Figure 15. DEA's Craftsmen's list showing examples of certified installers for air to air heat pump installations ${ }^{38}$

\begin{tabular}{|c|c|c|c|c|}
\hline \multicolumn{5}{|c|}{$\begin{array}{l}\text { Suppler med luft til luft- } \\
\text { Varmepumpe } \\
\text { Se alle fordelene ved at supplere med en luft tit luft-varmepumpe, og fá en liste over } \\
\text { hảndvæerkere, som kan udfore arbejdet. Hảndvæerkerne er alle medlem af en garantiordning } \\
\text { og er sorteret, sâ de matcher dig bedst. De bruger en energilosning, sả du fắr en } \\
\text { energieffektiv og fremtidssikret losning. }\end{array}$} \\
\hline TILBAGE TIL LOSNING > & & & & \\
\hline \multicolumn{5}{|l|}{ Her er dine håndværkere } \\
\hline Fyns Varmepumpecenter ApS & $\begin{array}{l}\text { Eskemosegyden } 63 \\
5600 \text { Faaborg }\end{array}$ & VE VE-godkendt & SENDE-MAIL & 曰 \\
\hline J. H. Mortensen El ApS & $\begin{array}{l}\text { Bjerrevej } 80 \text { - Dagnæes } \\
8700 \text { Horsens }\end{array}$ & VE VE-godkendt & SENDE-MAIL & ㅁ \\
\hline $\begin{array}{l}\text { Elektriker og Ejendomsudl v/Tom } \\
\text { Knud Jensen }\end{array}$ & $\begin{array}{l}\text { Agervej } 38 \text { B } \\
9970 \text { Strandby }\end{array}$ & VE VE-godkendt & SENDE-MAIL & 曰 \\
\hline Ollegaard El \& Koleteknik ApS & $\begin{array}{l}\text { Rentemestervej 32-34 } \\
2400 \text { Kobenhavn NV }\end{array}$ & ii: Energivejleder & SENDE-MAIL & $\square$ \\
\hline
\end{tabular}

A list of already certified installers can be found on DEA's website. ${ }^{39}$ By choosing an installer from the list the consumers would have the assurance that the installers are competent for installing their heat pumps correctly.

DEA has set up a consumer information website dedicated to give consumers and companies various information about saving energy. Below is an example showing the result of a consumer's search for approved installers for air to air heat pumps in a digital tool called "craftsmen's list". The ones marked with "VE-godkendt" are the certified installers for this technology. In addition, information brochures are developed to encourage consumers to hire certified installers. Furthermore Denmark has de-

\footnotetext{
$38 \mathrm{http}$ ///sparenergi.dk/forbruger/vaerktoejer/haandvaerkerlisten/varmepumpe/suppler-med-luft-til-luftvarmepumpe/annonce-company-view\#main-content

$39 \mathrm{http}: / /$ www.ens.dk/forbrug-besparelser/byggeriets-energiforbrug/ve-godkendelses-ordningen/listegodkendte-virksomheder
} 
veloped brochures for the installers and other interested about the new energy labels for heat pumps.

There is another voluntary certification scheme in Denmark, especially for installers of heat pumps. The scheme was established in 1994 of the heat pump industry and is known as VPO (VarmePumpeOrdningen). The scheme is financed by membership fees and education fee by providing training programs and courses for installers. The aim of the scheme is to ensure that heat pumps are dimensioned, installed and maintained correct in order to ensure that consumers who choose VPOinstallers have the maximum benefits of the installation. Although VPO and VE-Godkendelsesordningen both demand education and training of installers, there is no connection between the two certification schemes.

\section{Certified installers in Sweden}

In Sweden, heat pump installers are able to get certified by the trade association the Swedish cooling and heat pump association (SKVP, earlier the Swedish Heat Pump Association SVEP). An installer can be SVEPcertified by passing theoretical and practical tests in the EUCERT training program (EHPA certification program). A list of certified installers can be found on SKVP's website; however contact information of the installers is not presented.

The National Board of Housing, Building and Planning (Boverket) has, together with The Swedish Energy Agency and the Swedish Board for Accreditation and Conformity Assessment (Swedac) been responsible for starting a Swedish national certification scheme for heat pumps biomass and solar cells that fulfils the requirements according to the Renewable Energy Sources Directive.

A law was passed 31st December 2012, "Lag om certifiering av vissa installatörer". Boverket has adopted regulations (föreskrifter) with regards to certification of certain installers (including heat pump installers) and for the accreditation body for such certification and the Swedish Energy Agency regulations (föreskrifter) with regards to what installations that should be included in the certification scheme. 40,41

The certification scheme is voluntary. To be approved as certified installer it is required that the installers have general technical knowledge from relevant education or acquired through many years of professional activity as well as practical experience.

\footnotetext{
40 https://rinfo.boverket.se/CIN\%5CPDF\%5CBFS-2013-3-CIN-1.pdf

${ }^{41} \mathrm{http}: / /$ www.energimyndigheten.se/Global/Om\%20oss/F\%c3\%b6reskrifter/STEMFS\%202013_1.pdf
} 
The accreditation body is responsible for certification of the installers and for provision of continuously training of installers. The content of the training are specified in the rules. The aim is that installers shall have knowledge beyond the installations, as required by the Directive, for example of ecological aspects, regulation and rules.

Certification may be given for a maximum period of five years. In order to be certified again, when an earlier certification expires the installer shall in the past year have undergone brush-up training.

Installers certified according to the Swedish national certification scheme will be published on the webpage of the Swedish National Board of Housing Building and Planning (www.boverket.se).

\section{Certified installers in Finland}

In Finland, a list of certified installers for many different technologies can also be found on the website of energy authority (tukes). ${ }^{42}$ However the list is not dedicated to only installers for renewable energy systems. Furthermore the contact information of the certified installers is not presented on the list.

\section{Certified installers in Norway}

In Norway, there is the compulsory F-gas certification for installers. Since 1st September 2013 it has been illegal to install a heat pump unless the installer is F-gas certified. The company which the consumers buy the heat pump from should also be certified. F-gas certification regards Regulation (EC) No 842/2006 on fluorinated greenhouse gases, and is different from the certified installers regarding Article 14 of Directive 2009/28/EC.

As mentioned, a voluntary certification is also available in Norway, offered by the Norwegian Heat Pump Association NOVAP. ${ }^{43}$ Similar to the Danish heat pump association, NOVAP offers training technical programmes as well as certification courses for installers (including F-gas certification courses). The consumers are highly encouraged to hire NOVAPcertified installers, who have the competences to make sure consumers get the best, the most stable and economical operation in years to come. There is a search engine for different types of heat pumps. Once the type is chosen, a list of NOVAP-certified installers is presented with contact information and possibility to send an enquiry directly on the website, see Figure 16.

\footnotetext{
${ }^{42} \mathrm{http}: / /$ rekisterit.tukes.fi/sv/Urakoitsijat/Verksamhetsutovare/

${ }^{43}$ http://www.novap.no/
} 
Figure 16. Screenshots of a search for air to water heat pump NOVAP-certified installers, and the online enquiry form

Varmepumpetyper:

$\square$ Luft/Luft $\square$ Luft/vann $\square$ Vann/vann $\square$ Avtrekk-/ventilasjon

Velg fylke $\quad \checkmark$

Finn forhandler

Søk etter forhandlere som leverer Luft/vann varmepumper ga 246 treff:

\section{A. M. VIK AS}

F-gass godkjent bedrift

Comfort Syvde

TIf: 70023113

Ta kontakt Vis mer

A.I Varmepumper AS

F-gass godkjent bedrift

Stavangerveien 25

Tlf: 90401930

Ta kontakt Vis mer

ABD Rørservice AS

F-gass godkjent bedrift

Leira, Rissa

Tlf: 73851200

Ta kontakt Vis mer

Lukk

Bli kontaktet av A.I Varmepumper AS

Navn:

Epost:

Telefon:

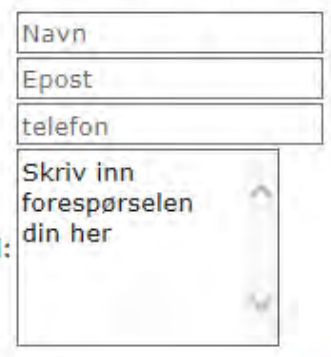

Send

A.I VARMEPUMPER AS 


\section{EUCERT}

European Heat Pump Association (EHPA) has also a European certification program for certified heat pump installers, known as EUCERT. The participating countries must have their own trade association to carry out the certification, the training materials etc. are received from EHPA. A database with all EUCERT certified heat pump installers can be found on their website sorted by countries. Although Denmark and Sweden are also participating countries, there is no certified installer in the database from these two countries. However many are found from Finland.

\section{Recommendations}

It is important that installers are aware of the new European ecodesign and energy labelling requirements that take effect in September 2015, and the possibility to use the new information on the label, in the product fiche and on the manufacturer's websites, in the communication with consumers.

An evaluation of Nordic installers' knowledge of energy labels and ecodesign requirements could be carried out to better support the subsequent activities. Nevertheless, the impression is that there is a need in the Nordic countries to educate installers in e.g. the new regulations and the applied measurement and calculation methods and in the understanding of the supplied information and how to use it.

It is recommended that the Nordic countries hold a workshop with regard to ecodesign and energy labelling as well as the Renewable Energy Sources Directive 2009/28/EC. The purpose should be exchange of lessons learned, how it works in practice and investigation of needs for continuing professional development. Nordic countries can afterwards cooperate on development of educational material and training courses. Other relevant aspects of common interest in the Nordic countries should of course be included (for instances aspects with regard to colder climate).

It is important that the installers use the additional knowledge in reality; therefore the installers should also be trained to find and ask for the energy efficiency class for colder climates when installing heat pumps in these regions. Especially for HP space heaters, HP combination heaters, HP water heaters and package products, the installers should look for/request product fiche to see efficiency for colder climate conditions.

As there are already national lists of certified installers in most of the Nordic countries, it is recommended to supplement the existing certification schemes so they comply with the requirements set by the Renewable Energy Sources Directive 2009/28/EC. 
It is also recommended to keep the certification procedures simple and easy to follow in each country. Information websites or brochures could include step by step instruction or checklists for getting certified.

Furthermore, the certified installers would only be helpful if the consumers are informed about them. Information websites or brochures should be developed to inform consumers about the benefits of hiring certified installers. Nordic SME survey showed that approx. $50 \%$ of manufacturers have consumers requesting for the certified installers when purchasing heat pumps, ${ }^{44}$ which means there is still need for widespread information dissemination. Finnish energy authorities could make efforts to promote the existing list of EUCERT certified installers for heat pumps, e.g. link to the EUCERT installer database on websites where consumers could read about or purchase heat pumps.

To encourage consumers to contact certified installers, it is also recommended that the contact information should be shown on the lists, the Danish and Norwegian examples can be inspirations.

It is important that installers have access to the newest knowledge about heat pumps efficiency and tools to inform the consumers (including energy labelling, lists etc.). Therefore one of the essential recommendations is that the countries shall ensure that installers education are supplemented/refreshed when relevant and at regular basis. Small digital tools or online videos could be developed for this purpose. In Denmark, small videos are for instance used for training of salesman in shops.

${ }^{44}$ Preliminary results from survey to Nordic SME conducted by M. Kapanen, January 2015. 


\section{Recommendations for cooperation and actions}

This section concludes the project by presenting consultants' recommendations to Nordsyn and the Nordic energy authorities. The recommendations are based on the collected information, the study activities carried out in the project (including interviews with selected experts) and the consultants' experience from various works with energy efficient product, ecodesign and energy labelling of products as well as market surveillance activities. Furthermore the results from the Nordic SME survey have been consulted.

\section{General recommendations}

A Danish investigation of lessons learned from implementation of policy measures for promotion of heat pumps has come up with some important key points that are considered to be essential. 45

- Firstly, it is important as a first step to build consumer confidence in the heat pump technology.

- Secondly, there must be quality and confidence throughout the whole value chain - installers and contractors must trust heat pump technology, and consumers must trust the quality of the product, installation and on-going maintenance.

- Finally, quality most come first and promotion afterwards.

It is a recommendation to be aware of the above mentioned points when considered overall strategies to promote the heat pump technology in the Nordic countries.

Many ongoing activities are in line with the key points mentioned above but it is important also in the future to be aware of the importance of quality and confidence.

${ }_{45}$ Policy measures for heat pump market growth. DELTA Energy \& Environment for Danish Energy Agency. December 2013. 
Examples of activities to improve quality of heat pumps and consumer confidence are heat pumps lists, quality marking, test programs, EU energy labelling and ecodesign requirements, certified installers, various information dissemination activities and market surveillance.

This kind of measures should be continued and further developed in the years to come.

\section{Recommendations on Nordic cooperation}

The projects have pointed out some issues where it would be appropriate for Nordic countries to cooperate, for instance, to obtain more influence in the EU, to share experiences and knowledge and to reduce costs. Recommendations with regard to cooperation are summarised as follows:

\section{Cooperation to influence EU decisions}

In order to influence European regulations with regard to ecodesign and labelling, it is recommended that when the energy labelling and ecodesign regulations are due for revision, the Nordic countries propose that:

- For air to air heat pumps, it should be mandatory and not optional to indicate efficiency for all climate zones (or for the climate zone of the country where the heat pump is placed on the market) on the energy label, this information should also be added to product fiche, and websites of manufacturers etc.

- For HP space heaters, HP combination heaters and HP water heaters, it should be mandatory to indicate efficiency for all climate zones (or for the climate zone of the country where the heat pump is placed on the market) on the energy label and websites of manufacturers etc. (it is already required to state in product fiche).

- All energy labels of heat pumps should indicate the sound power levels in a scale of $A-G$ (for instance $A B C D E F G$ or $A B C D E F G$ ). See section 7.

- Ecodesign requirement with regard to sound power levels should be made more ambitious.

- Separate ecodesign requirements for the different energy technologies/carriers (such as electricity, oil and gas) are set in regulation $814 / 2013.46$

${ }^{46}$ Article 7 Review paragraph 2. 
- The Nordic countries consider pushing for third part certification, especially for the most expensive heat pump systems.

Appropriateness of third part certification is one of the issues for space heaters that, according to the ecodesign regulation, should be considered in connection with the revision of the regulation.

In order to support the points above, consider carrying out an investigation of the effect climate zones have on efficiency class, and the usefulness of information on the energy label when the information does not correspond to the actual climate zone where the heat pump is installed. This could involve testing of a number of heat pumps in different climate conditions. It is in all cases important to prepare the input and proposals well in advance, in order to be able to give appropriately designed proposals supported by realistic data on, for instance, the sound power level.

\section{Cooperation on market surveillance activities}

The Nordic countries are already cooperating in the field of market surveillance, for instance, in coordination of market surveillance plans, elaboration of TD-guides, factsheets and exchange of test results and experiences. It is recommended to continue and extend the cooperation.

The following activities are recommended:

- Evaluation of existing TD-guides and factsheets for heat pumps (developed on behalf of Nordsyn and NVE). The evaluation should emphasize on the usability of the guides and factsheets and how they could be improved (i.e. are the manufactures aware of the guides and do they find the content applicable).

- Testing of heat pumps is very expensive. The Nordic countries could cooperate to develop less expensive screenings tests.

- Closer cooperation with regard to coordination of market surveillance plans with regard to testing and inspection of technical documentation. For instance a common information sharing platform could be established. A possibility is to use the common EU ICSMS data base. The plans should be uploaded as early as possible each year. This requires that each country elaborate the plans early. (The Nordic Authorities could decide on a deadline).

- Exchange of results of inspection of technical documentation for heat pumps. Today the main focus is on exchange of results of tests. However results of technical documentation control could also be useful. Due to the costs, only few products are tested each year. 
- Cooperation of the Nordic countries when interacting with the ADCO working group. The Nordic countries should work together on the questions to be raised and a collective plan before the ADCO meetings, so the questions can be coordinated to clarify essential issues common to the Nordic conditions.

- That the Nordic countries coordinate information to the manufacturer/heat pump association after consultation with the ADCO group.

Some of the recommendations mentioned above are not only relevant for heat pumps but for all products covered by ecodesign and energy labelling regulations.

\section{Heat pump lists}

Heat pump lists and quality labels are considered to be very useful tools to improve the quality of the heat pumps and create consumer's confidence. Heat pump list and quality labels already exist in Denmark (heat pump list) and in Sweden (P-marking and SEA's heat pump tests).

It is recommended:

- that all heat pump list and quality marks in the future as far as possible is based on the measurement and calculations methods used in the ecodesign and energy labelling regulations. The requirements should be more ambitious that the applicable ecodesign requirement (to create added value)

- to reduce the number of lists and quality marks to a minimum. Too many lists and quality marks may create uncertainty and reduce the confidence of consumers

- that it is required that lists when relevant shows the energy efficiency class etc. of the heat pump in cold climate zone

- to require that heat pumps on the lists shall meet requirements with respect to maximum allowed sound power levels

- to consider establishing a common Nordic heat pump list that take into account specific Nordic conditions such as the colder climate zone. The common list could operate alongside national lists as long as it builds on harmonized measurement and calculation methods. One important principle should be that the manufacturers only need to apply once. A first step could be to discuss the possibility with Nordic heat pump associations and relevant stakeholders. 


\section{Certified installers}

It is important that companies that size and install heat pumps have the necessary competences. The purpose of the certified installers is to ensure that the companies have a proper quality management system and that the employees have the relevant education and competences.

The Nordic countries should ensure that all certified installers have knowledge about the new regulations with regard to ecodesign and energy labelling of heat pumps and the applied measurement and calculation methods. It is important that the installers know how they could use the information on the energy label and product fiche in dialogue with the consumers etc.

The Nordic countries have implemented the schemes of certified installers in different ways with respect to training and education of employees of the installer, need for a brush-up of education etc. Furthermore the level of information about the installers varies from country to country.

It is recommended:

- that an evaluation of the experiences with certified installers in the Nordic countries is carried out

- that the Nordic countries hold a workshop for the implementation of the Renewable Energy Sources Directive 2009/28/EC with respect to certified installers in particular for heat pumps. The purpose should be exchange of lessons learned, how it works in practice and investigation of needs for continuing professional development. Results of the evaluation mentioned above could provide important input to the discussions

- that the installers' education is updated regularly and especially in periods before application of new standards and legislation, before new information tools is made available etc.

- that there should be ongoing development of education materials, for instance digital learning tools or online videos for installers. Relevant aspects of common interest in the Nordic countries should also be included (for instances colder climate zones)

- the installers can also be trained to find and ask (the supplier/manufacturer) for the energy efficiency class (and other relevant information) for colder climate zones when selecting and installing heat pumps regions with cold climate

- to keep the certification procedures simple and easy to follow in each country. Information websites or brochures could include step by step instruction or checklists for getting certified 
- that information websites or brochures should be developed to inform consumers about the benefits of hiring certified installers. Most Nordic countries already have a webpage with a list of certified installers. The webpage could be redesigned so consumers easily can get access to information of certified installers, so that contact information including phone number and e-mail address are presented (some countries already do).

\section{Display of energy efficiency class, yearly energy consumption etc. for colder climate conditions}

Since EU regulations do not require to show efficiency class for colder (or warmer climate) on energy labels, the Nordic manufacturers can differentiate themselves on the Nordic market by doing so. If the energy efficiency class, annual energy consumption etc. are displayed for the relevant climate conditions of the country, consumer will be better informed and be able to choose a heat pump matching the real life conditions.

It is recommended:

- the Nordic authorities suggest and encourage manufacturers to indicate energy efficiency class for colder climate in addition to energy efficiency class for average climate for air to air heat pumps on the energy labels and in the product fiche

- that the Nordic authorities suggest and encourage the manufacturers to show the energy efficiency class, rated output and annual energy consumption for colder climate conditions for HP space heaters, HP combination heaters and HP water heaters on free access websites, alternatively the information in product fiches can be displayed on websites

- that the energy authorities engage in dialogue with Nordic heat pump associations and manufacturers regarding this issue

- that the energy authorities consider holding a common Nordic workshop to discuss the possibilities and find a solution (a kind of voluntary agreement could be a possibility).

\section{Off-Peak tariffs for load shifting}

Load shifting to off-peak periods by heat pumps is demonstrated successful by real-life experiment as well as simulations. Most households can shift their electricity demand of heat pumps to off-peak periods with a large buffer tank and load shifting is also found to be well suited for high thermal mass and well-insulated buildings. However the Off-Peak tariffs need to be low enough, as the electricity consumption of the household 
could actually increase, hence if the difference between Off-Peak and normal tariffs is small, the consumers could end up paying more.

It is recommended:

- that the Nordic energy authorities encourage the electricity companies to offer attractive Off-Peak tariffs

- that the economic and environmental benefits of heat pump load shifting are communicated clearly to consumers. Furthermore the consumers should be informed about details with regard to which types of houses are suitable for shifting to low peak periods, what the requirement for thermal mass is, and how large the buffer tank should be to cover the heat demand etc.

- that the Nordic countries consider launching a pilot project on searching for effective "nudging" methods to encourage consumers to shift their energy demand to off-peaks via heat pumps. The pilot project should calculate typical home savings to support a possible information campaign and also conclude what types of "nudging" method is most suitable for different Nordic countries.

\section{Sound power level}

Heat pumps make noise both in indoor and outdoor environments (dependent on the type of heat pump). Especially for air to water heat pump the outdoor noise could both disturb the owner of the heat pump and neighbours if the heat pump is not located appropriately.

It is recommended:

- that the Nordic countries cooperate, upon revision of regulations, to improve information about sound power level on the energy label and strengthen ecodesign requirements for sound power level

- in the meantime, information activities for heat pumps could be prepared in the Nordic countries to educate consumers about sound power levels of heat pumps

- that the energy authorities consider including some aspects of noise in national legislation such and building and environmental regulations by including a guide on how to control and minimize the noise level by choosing suitable heat pump and a feasible location.

Please also see recommendation with regards to sound power level in section about Nordic cooperation. 


\section{Information for the consumers}

It is very important that consumers have confidence in the heat pump technology and have access to reliable and credible information about heat pumps.

Various information activities have already been carried out in the each of the Nordic countries including websites, independent advice services, leaflets etc.

It is recommended:

- to carry out a Nordic evaluation of a number of selected information activities, to investigate how they are used by the consumers and to what extent they contribute to increasing the consumer's confidence in heat pumps. The results of the evaluation can point out topics for future Nordic projects regarding information dissemination to the consumers

- to consider a dedicated webpage with all relevant information, checklist and advice about choosing, buying, installing and operating heat pumps, the heat pump page on Danish and Norwegian consumer websites SparEnergi.dk and forbrukerradet.no can be inspirations. 


\section{References}

Academia. Performance assessment of tariff-based air source heat pump load shifting in a uk detached dwelling featuring phase change-enhanced buffering: https://www.academia.edu/6306064/PERFORMANCE_ASSESSMENT_OF_TARIFFBASED_AIR_SOURCE_HEAT_PUMP_LOAD_SHIFTING_IN_A_UK_DETACHED_DWELLI NG_FEATURING_PHASE_CHANGE-ENHANCED_BUFFERING

Boverkets författningssamling (2013) Boverkets föreskrifter och allmänna råd (2013:3) om certifiering av vissa installatörer samt om ackreditering av or-gan för sådan certifiering: https://rinfo.boverket.se/CIN\%5CPDF\%5CBFS-2013-3-CIN-1.pdf

DELTA Energy \& Environment for Danish Energy Agency (December 2013) Policy measures for heat pump market growth.

Energimyndigheten (2009) Heta Värmepumpar - Sverige ledande på pumpar. ET2009:23.

Energimyndigheten (2015) Värmepumparnas roll på uppvärmningsmarknaden, ER 2015:09.

Energinet: http://energinet.dk/DA/FORSKNING/Energinet-dks-forskning-ogudvikling/Sider/Fra-vindkraft-til-varmepumper.aspx

Energistyrelsen. Liste over godkendte virksomheder: http://www.ens.dk/forbrugbesparelser/byggeriets-energiforbrug/ve-godkendelses-ordningen/listegodkendte-virksomheder

Energisytelsen. Støjberegner: http://www.ens.dk/forbrug-besparelser/byggerietsenergiforbrug/varmepumper/stojberegner

Energistyrelsen (2013). Brug af nudging til at øge energieffektivisering.

Energistyrelsen (2014) Hvad står der i energimærkerne? http://www.ens.dk/sites/ens.dk/files/forbrug-besparelser/apparater-produkter/ energimaerkning-apparater-produkter/installatoerer/ hvad_staar_der_paa_energimaerkerne-_ikonforklaring.pdf

Energistyrelsen (2015) http://sparenergi.dk/forbruger/varme/raadgivningstjeneste

ENOVA. Våre tilbod: http://www.enova.no/finansiering/privat/slik-stotter-videg/vare-tilbud/904/0/

ENOVA. Støtte til varmesentraler. http://www.enova.no/finansiering/naring/ fornybar-varme/program-for-varmesentraler/120/0/

ENOVA. Kjøpsveileder luft/luft varmepumpe: http://www2.enova.no/ publikasjonsoversikt/publicationdetails.aspx?publicationID $=659$

ENOVA (2014) Kjøpsveileder luft/luft-varmepumpe - En veileder fra Enova og Miljødirektoratet.

EUR-LEX (2011) Energy labelling regulation on air conditioners (EU) No 626/2011: http://eur-lex.europa.eu/LexUriServ/LexUriServ.do?uri=0J:L:2011:178:0001:0072: EN:PDF

EUR-LEX (2012) Ecodesign regulation on air conditioner (EU) No 205/2012: http://eur-lex.europa.eu/LexUriServ/LexUriServ.do?uri=0J:L:2012:072: 0007:0027:EN:PDF 
EUR-LEX (2013) Ecodesign regulation on boilers and heat pumps (EU) No 813/2013: http://eurlex.europa.eu/LexUriServ/LexUriServ.do?uri=0J\%3AL\%3A2013\%3A239\%3A0136 \%3A0161\%3AEN\%3APDF

EUR-LEX (2013) Energy Labelling regulation on boilers, heat pumps and packages (EU) No 811/2013: http://eurlex.europa.eu/LexUriServ/LexUriServ.do?uri=0J\%3AL\%3A2013\%3A239\%3A0001 $\% 3 \mathrm{A0082 \% 3AEN \% 3APDF}$

EUR-LEX (2013) Ecodesign regulation on water heaters and heat pump water heaters (EU) No 814/2013: http://eur-

lex.europa.eu/LexUriServ/LexUriServ.do?uri=0J\%3AL\%3A2013\%3A239\%3A0162 \%3A0183\%3AEN\%3APDF

EUR-LEX (2013) Energy Labelling regulation on water heaters, heat pump water heats and hot water storage tanks and packages (EU) No 812/2013: http://eurlex.europa.eu/LexUriServ/LexUriServ.do?uri=0J\%3AL\%3A2013\%3A239\%3A0083 \%3A0135\%3AEN\%3APDF

Forbrukerrådet (20.03.2012) Den store varmepumpeguiden: http://www.forbrukerradet.no/annet/tester-og-kj\%C3\%B8petips/ produkter/den-store-varmepumpeguiden

Forbrukerrådet (26.11.2012) Mitsubishi-varmepumper testet: http://www.forbrukerradet.no/annet/tester-og-kj\%C3\%B8petips/ produkter/rekordresultater-for-ny-varmepumpe

Grontmij. (December 2012) Styr på støjen - en guide til installation af luft til vand varmepumper. Udarbejdet for Energistyrelsen.

Ingeniøren (28.10.2013) Nu kan du sammenligne varmepumpers effektivitet over en hel dansk vinter: http://ing.dk/artikel/nu-kan-du-sammenligne-varmepumperseffektivitet-over-en-hel-dansk-vinter-163728

Kapanen, M. (2015). Preliminary results from survey to Nordic SME conducted by M. Kapanen, January 2015.

Kapanen, M. (2015). Survey to Nordic SME conducted by M. Kapanen, January 2015. Larsen, T.F. (2014). NORDSYN Market surveillance effects and costs.

Modstrøm: https://www.modstroem.dk/privat/produkter/ideel

Norsk forening mot Stoy (2013). Varmepumper av siv.ing. Jan Oddvar Fro. http://www.stoyforeningen.no/Nyheter/Varmepumper

NOVAP: http://www.novap.no/

Retsinformation. Ansøgning og uddannelseskrav: m.v.https://www.retsinformation.dk/Forms/R0710.aspx?id=158160\#Kap3

Sekretariatet for Ecodesign og Energimærkning af Produkter (2014) Resultater af Energistyrelsens kontrol: http://www.ens.dk/sites/ens.dk/files/forbrugbesparelser/apparater-produkter/tilsynkontrol/kontrolresultater/kontrol_klimaanlaeg.pdf

Sekretariatet for Ecodesign og Energimærkning af Produkter (2015) Rapport for undersøgelse af brugernes opfattelse af Sekretariatet for Ecodesign og Energimærkning af Produkters. Besvarelse af henvendelser samt brugernes anvendelse af Energistyrelsens vejledninger.

Skat (2014) http://www.skat.dk/SKAT.aspx?oID=2061620\&chk=209219

SparEnergi. Varmepumpelisten: http://sparenergi.dk/forbruger/vaerktoejer/ varmepumpelisten 
SparEnergi: http://sparenergi.dk/forbruger/vaerktoejer/haandvaerkerlisten/ varmepumpe/suppler-med-luft-til-luft-varmepumpe/annonce-companyview\#main-content

SP Sveriges Tekniska Forskningsinstitut: P-märkta värmepumpar: http://www.sp.se/SV/INDEX/SERVICES/CERTPROD/CERTPRODPROFIL/BYGG/U PPVARMN/VARMEPUMPAR/Sidor/default.aspx

SP Sveriges Tekniska Forskningsinstitut (2014) P-marking of construction Products. Certification Rules 130. Heat Pumps. http://www.sp.se/sv/units/energy/ Documents/ETk/CR\%20130\%20september\%202014_141001_english.pdf

SP Sveriges Tekniska Forskningsinstitut: https://energimyndigheten.aw2m.se/Home.mvc

Statens Byggeforskningsinstitut. Requirements for heat pumps in the Danish Building Regulations (BR10): http://anvisninger.dk/Publikationer/Sider/ Anvisning-om-Bygningsreglement-2010.aspx/8-Installationer/8-6Solvarmeanlaeg-solcelleanlaeg-koeleanlaeg-og-varmepumper/8-6-4Varmepumper-og-koeleanlaeg

Statens energimyndighets författningssamling (2013) Statens energimyndighets föreskrifter om anläggningar som omfattas av system för certifiering av vissa installatörer: http://www.energimyndigheten.se/Global/0m\%20oss/ F\%c3\%b6reskrifter/STEMFS\%202013_1.pdf

Swedish Energy Agency (2014). Test of air-to-air heat pumps.

Tukes. Verksamhetsutövare som finns i Tukes register (installations-, service- och reparationsverksamhet): http://rekisterit.tukes.fi/sv/Urakoitsijat/ Verksamhetsutovare/

www.varmepumpeinfo.no: Støtte til varmepumper fra Enova (18.12.2014) http://www.varmepumpeinfo.no/content/stotte-til-varmepumper-fra-enova www.varmepumpeinfo.no. Forhandlere: http://www.varmepumpeinfo.no/forhandlere 



\section{Sammanfattning}

Inom Nordsyn-samarbetet har de nordiska länderna - Danmark, Sverige, Norge, Finland och Island utfört ett projekt om strategiska nordiska produkter och värmepumpar valdes att studeras inom detta projekt. Värmepumpar är strategiska nordiska produkter eftersom deras optimering påverkas av klimatet och det finns en stark industri och historia i de nordiska länderna. Syftet med denna studie är att skapa en överblick över lagstiftning, nationella system och åtgärder som vidtagits för att främja energieffektiva värmepumpar, samt att diskutera ett antal frågeställningar som kommit upp i och med kraven på ekodesign och energimärkning för värmepumpar och aktuell marknadskontroll.

I studien diskuteras aktuella frågeställningar och rekommendationer ges om ytterligare åtgärder som kan genomföras av de nordiska myndighetenar. Åtgärder som pekas ut som lämpliga för nordiskt samarbete är främjandet av märkning av effektivitet i kallt klimat, en möjlig nordisk värmepumplista, främjandet av bullerinformation, samarbete kring tester, att arbeta tillsammans med information och att hålla workshops för certifierade installatörer och för kallt klimat -märkning.

Denna rapport är en del av de nordiska statsministrarnas grön växt initiativ under Nordiska ministerrådet. Se mer på www.norden.org/ greengrowth 



\section{Annex A}

\section{Definitions in EU ecodesign and energy labelling regulations for heat pumps}

Air to air heat pumps (air conditioners) means a device capable of heating indoor air, using a vapour compression cycle driven by an electric compressor including air conditioners that provide additional functionalities such as dehumidification, air purification, ventilation or supplemental air heating by means of electric resistance heating and appliances that may use water (wither condensate water that is formed on the evaporator side or externally added water) for evaporation on the condenser, provided that the device is also able to function without the use of additional water, using air only. 47,48

Heat pump space heater means a space heater using ambient heat from an air source, water source or ground source, and/or waste heat for heat generations; a heat pump space heater may be equipped with one or more supplementary heaters using the Joule effect in electric resistance heating elements or combustion of fossil and/or biomass fuels. ${ }^{49}$

Heat pump combination heater means a heat pump space heater that is designed to also provide heat to deliver hot drinking or sanitary water at given temperature levels, quantities and flow rates during given intervals, and is connected to an external supply of drinking or sanitary water.

Package of heat pump space heater, temperature control and solar device means a package offered to the end-user containing one or more heat pump space heaters combined with one or more temperature controls, and/or one or more solar devices. 50

\footnotetext{
${ }^{47}$ Ecodesign regulation on air conditioner (EU) No 205/2012: http://eur-lex.europa.eu/LexUriServ/ LexUriServ.do?uri=0J:L:2012:072:0007:0027:EN:PDF

48 Energy labelling regulation on air conditioners (EU) No 626/2011: http://eur-lex.europa.eu/LexUriServ/ LexUriServ.do?uri=0J:L:2011:178:0001:0072:EN:PDF

${ }^{49}$ Ecodesign regulation on boilers and heat pumps (EU) No 813/2013 http://eur-lex.europa.eu/LexUriServ/ LexUriServ.do?uri=0J\%3AL\%3A2013\%3A239\%3A0136\%3A0161\%3AEN\%3APDF

${ }^{50}$ Energy Labelling regulation on boilers, heat pumps and packages (EU) No 811/2013 http://eur-lex.europa.eu/ LexUriServ/LexUriServ.do?uri=0J\%3AL\%3A2013\%3A239\%3A0001\%3A0082\%3AEN\%3APDF
} 
Package of heat pump combination heater, temperature control and solar device means a package offered to the end-user containing one or more heat pump combination heaters combined with one or more temperature controls, and/or one or more solar devices.

Heat pump water heater means water heating using ambient heat from an air source, water source or ground source and/or waste heat from heat generation. ${ }^{51,52}$

${ }^{51}$ Ecodesign regulation on water heaters and heat pump water heaters (EU) No 814/2013 http://eurlex.europa.eu/LexUriServ/LexUriServ.do?uri=0J\%3AL\%3A2013\%3A239\%3A0162\%3A0183\%3AEN\%3APDF

52 Energy Labelling regulation on water heaters, heat pump water heats and hot water storage tanks and packages (EU) No 812/2013 http://eur-lex.europa.eu/LexUriServ/LexUriServ.do?uri=0J\%3AL\%3A2013\%3A239\% 3А0083\%3A0135\%3AEN\%3APDF 
Ved Stranden 18

DK-1061 Copenhagen K

www.norden.org

\section{Strategic Nordic Products - Heat pumps}

The project Strategic Nordic Products - Heat pumps, includes an overview of legislation, national schemes and actions taken to promote energy efficient heat pumps, and makes recommendations on further actions and possible cooperation to be carried out by Nordic authorities. The project is part of Nordsyn under the Nordic Prime Ministers' overall green growth initiative: "The Nordic Region - leading in green growth" - read more at www.norden.org/greengrowth. 